Article

\title{
Comparative Study of Mercury(II) Removal from Aqueous Solutions onto Natural and Iron-Modified Clinoptilolite Rich Zeolite
}

\author{
Marin Ugrina ${ }^{1, *}$ (D), Teja Čeru ${ }^{2}$, Ivona Nuić ${ }^{1}$ (D) and Marina Trgo ${ }^{1}$ \\ 1 Department of Environmental Engineering, Faculty of Chemistry and Technology, University of Split, \\ Ruđera Boškovića 35, 21000 Split, Croatia; ivona@ktf-split.hr (I.N.); marina.trgo@ktf-split.hr (M.T.) \\ 2 Department of Mineral Resources and Geochemistry, Geological Survey of Slovenia, Dimičeva Ulica 14, \\ 1000 Ljubljana, Slovenia; teja.ceru@geo-zs.si \\ * Correspondence: mugrin@ktf-split.hr; Tel.: +385-21-329-454
}

Received: 29 October 2020; Accepted: 18 November 2020; Published: 23 November 2020

\begin{abstract}
The contamination of soil and water bodies with mercury from anthropogenic sources such as mining and industry activities causes negative effect for living organisms due to the process of bioaccumulation and biomagnification through the food chain. Therefore, the need for remediation of contaminated areas is extremely necessary and very desirable when it is cost-effective by using low-cost sorbents. This paper compares the sorption abilities of natural and iron-modified zeolite towards $\mathrm{Hg}(\mathrm{II})$ ions from aqueous solutions. The influence of $\mathrm{pH}$, solid/liquid ratio $(\mathrm{S} / \mathrm{L})$, contact time, and initial concentration on the sorption efficiency onto both zeolites was investigated. At the optimal $\mathrm{pH}=2$ and $\mathrm{S} / \mathrm{L}=10$, the maximum amount of sorbed $\mathrm{Hg}(\mathrm{II})$ is $0.28 \mathrm{mmol} / \mathrm{g}$ on the natural zeolite and $0.54 \mathrm{mmol} / \mathrm{g}$ on the iron-modified zeolite. It was found that rate-controlling step in mass transfer is intraparticle diffusion accompanied by film diffusion. Ion exchange as a main mechanism, accompanied with surface complexation and co-precipitation were included in the $\mathrm{Hg}$ (II) sorption onto both zeolite samples. This is confirmed by the determination of the amount of sorbed $\mathrm{Hg}(\mathrm{II})$ and the amount of released exchangeable cations from the zeolite structure as well as by the scanning electron microscopy (SEM) and energy dispersive X-ray analysis (EDS) of saturated zeolite samples. In a wide $\mathrm{pH}$ range, $4.01 \leq \mathrm{pH} \leq 11.08$, the leaching of $\mathrm{Hg}$ (II) was observed in the amount of only $0.28-0.78 \%$ from natural zeolite and $0.07-0.51 \%$ from iron-modified zeolite indicating that both zeolites could be used for remediation purposes while the results suggest that modification significantly improves the sorption properties of zeolite.
\end{abstract}

Keywords: natural zeolite; iron-modified zeolite; mercury(II); sorption; leaching

\section{Introduction}

Environmental mercury pollution is a serious problem due to its high mobility in the environment and extreme toxicity to human health. The main sources of mercury emissions into the environment comes from natural (volcanic emissions, mineral deposits), anthropogenic (coal combustion, mining processing), and reemitted resources (already mercury contaminated sites) where the most significant are the anthropogenic ones. From all mentioned sources, mercury is emitted into the atmosphere, soils, or water systems where it remains permanently due to its non-biodegradable properties [1-3]. It could appear in inorganic forms such as $\mathrm{Hg}^{\mathrm{o}}, \mathrm{Hg}(\mathrm{I}), \mathrm{Hg}$ (II), as well as in organic forms such as non-volatile mono methyl-mercury $\left(\mathrm{CH}_{3} \mathrm{Hg}^{+}\right)$and volatile dimethyl-mercury $\left[\left(\mathrm{CH}_{3}\right)_{2} \mathrm{Hg}\right]$. Methylation of $\mathrm{Hg}$ (II) takes place in anoxic conditions under the influence of reducing bacteria present in the soil. The formed mono methyl-mercury poses a greater danger than $\mathrm{Hg}$ (II) due to higher mobility and the tendency 
of bioaccumulation and biomagnification through the food chain $[4,5]$. Thus, in soils and aquatic sediments, mercury species can be trapped by clays and more often by organic matter such as fluvic and humic acids in acidic soils [2,5]. On the other hand, trapped mercury can be released into the environment and undergo complex physical, chemical, and biological transformations and distributed into the deeper layers of the soil, towards even groundwater [1-3]. Therefore, the World Health Organization has given a recommendation on the maximum permissible concentration of mercury in drinking water of the amount up to $1 \mu \mathrm{g} / \mathrm{L}$ [6]. This value indicates the extremely high toxicity of mercury in all its forms and suggests the need for remediation in already existing contaminated sites or preventing the spread of contamination from these sites. The most vulnerable areas are groundwater and aquifers that can be contaminated by the percolation of mercury leachate from polluted soils and sediments [7]. In order to prevent the migration of its species from contaminated soil to deeper soil layers, various ex situ and in situ remediation techniques are used $[1,2,8]$. Ex situ methods involve the excavation of contaminated soil, sediment, or waters as well as the subsequent removal of mercury by a suitable remediation technique. In contrast, in situ methods are applied at the site of contamination, commonly in the form of permeable reactive barrier filled with a material that will immobilize the mercury or by sprinkling the soil with active material. When comparing both, in situ methods are more easily feasible and their limitation is that the immobilizing material must have a high affinity for mercury without the possibility of releasing trapped mercury from its structure. Therefore, the choice of material is very challenging because it should be very efficient, capable of keeping mercury inside the structure, and compatible with the environment without causing additional environmental pollution [9]. According to the literature, activated carbon seems to be highly efficient in mercury sorption, but the costs of its preparation indicate that it does not belong to cost-effective sorbents $[10,11]$. Therefore, environmentally-friendly sorbents such as natural zeolite can be promising since various sorbents are easily available today. Natural zeolites are naturally occurring materials and are recognized as efficient materials in environment remediation [12-14]. They are compatible with nature since they do not introduce additional contaminations to the environment. The structure of zeolites consists of the three-dimensional frameworks of $\mathrm{SiO}_{4}$ and $\mathrm{AlO}_{4}$ tetrahedra. The negative charge of the zeolite structure is a consequence of the isomorphous replacement of $\mathrm{Si}^{4+}$ with $\mathrm{Al}^{3+}$ which is balanced by the presence of exchangeable cations, primarily $\mathrm{Na}, \mathrm{K}, \mathrm{Ca}$, and $\mathrm{Mg}$. These cations have the ability to participate in the ion exchange process with heavy metals cations in the solutions. Additionally, modifications of zeolites with acids, bases, surfactants, and inorganic salts are performed in order to enhance their sorption capacity towards cationic, anionic, and organic compounds [12].

Inorganic compounds such as Fe or Mn oxide and oxyhydroxide have shown a strong affinity for heavy metal ions since they possess oxygen-containing functional groups that are responsible for interactions with heavy metals through chemical sorption or redox reactions $[11,15]$. Thus, many researchers have confirmed a significant increase in the sorption capacity of modified zeolite with $\mathrm{Fe}(\mathrm{III})$ salts towards $\mathrm{Cu}(\mathrm{II}), \mathrm{Mn}(\mathrm{II}), \mathrm{Zn}(\mathrm{II}), \mathrm{Pb}(\mathrm{II})$, and $\mathrm{Cd}(\mathrm{II})$ [16-21]. Regarding the removal of $\mathrm{Hg}(\mathrm{II})$, Chojancki et al. [22] applied natural zeolites, while Gebremedhin-Haile et al. [23] and Misaelides and Godelistas [24] applied zeolite pretreated with $\mathrm{NaCl}$. The results of their investigations showed that pretreatment with $\mathrm{NaCl}$ improves zeolite sorption properties.

The present study compares the sorption properties of natural (NZ) and iron-modified zeolite (FeZ) towards $\mathrm{Hg}$ (II) from aqueous solutions through the investigations of different parameters that affect the sorption processes, as well as the elucidate sorption and mass transfer mechanism. In order to assess the possible application of the $\mathrm{NZ}$ and $\mathrm{FeZ}$ for the in situ remediation of mercury-contaminated groundwater or soil, beside sorption experiments, the retention strength of sorbed mercury in saturated zeolite is investigated by using the standard leaching test in different $\mathrm{pH}$ values. 


\section{Materials and Methods}

\subsection{Sample Preparation and Characterization}

The starting sample, natural zeolite (NZ) was collected from the Zlatokop deposit (Vranjska Banja, Serbia). The sample was milled, sieved, and a particle size fraction of $0.6-0.8 \mathrm{~mm}$ was separated. Thereafter, the sample was washed in ultrapure water and dried at $60{ }^{\circ} \mathrm{C}$.

Iron-modified zeolite (FeZ) was prepared via the treatment of $\mathrm{NZ}$ according to the procedure published previously [21]. Briefly, the procedure consisted of 3 separated stages. Firstly, the sample was mixed with a $1 \mathrm{~mol} / \mathrm{L} \mathrm{Fe}\left(\mathrm{NO}_{3}\right)_{3} \cdot 9 \mathrm{H}_{2} \mathrm{O}$ freshly prepared solution by dissolving iron salt in an acetate buffer at $\mathrm{pH}=3.6$, followed with $1 \mathrm{~mol} / \mathrm{L} \mathrm{NaOH}$ and $4 \% \mathrm{NaNO}_{3}$ solutions. The prepared sample was dried at $40{ }^{\circ} \mathrm{C}$ and kept in a desiccator until use. Detailed physico-chemical characterization of both, NZ and FeZ (chemical composition, scanning electron microscopy with energy dispersive $X$-ray analysis (SEM/EDS), X-ray diffraction '(XRD), Fourier-transform infrared spectroscopy (FTIR), BET (Brunauer, Emmett and Teller) specific surface area, thermogravimetry and derivative thermogravimetry(TG/DTG) was performed and explained in detail in a previously published paper [21]. The mineralogical composition of natural zeolite was primarily clinoptilolite (minimum $80 \%$ ) with quartz, feldspar, and carbonates as accompanying minerals, as determined by XRD analysis. It was observed that the modification caused a slight decrease in crystallinity (XRD), the broadening of characteristic hydroxyl bands, O-H stretching (FTIR), a slight increase in the specific surface area and a significant increase in pore volume (BET), as well as a higher mass loss (TG/DTG). Chemical analysis showed an almost double increase in the amount of iron while the amount of sodium increased three times, which was also confirmed by the analysis of the elemental composition of the NZ and FeZ surfaces (SEM/EDS). The main exchangeable cation was calcium for NZ and sodium for FeZ sample. The increase in the point of zero charge for $\mathrm{FeZ}\left(\mathrm{pH}_{\mathrm{pzc}}=9.8 \pm 0.1\right)$ by three $\mathrm{pH}$ units in relation to $\mathrm{NZ}\left(\mathrm{pH}_{\mathrm{pzc}}=6.8 \pm 0.1\right)$ was a consequence of the increase in the net negative charge of zeolite due to the modification process. Thus, the purpose of the modification process was to increase the zeolite sorption sites by the sorption of Fe hydroxyl species on the negative zeolite surface, among which $\mathrm{Fe}_{3}(\mathrm{OH})_{4}{ }^{5+}$ dominates at $\mathrm{pH}=3.6$. The binding mechanism of Fe hydroxyl species can be described as follows [25]:

$$
\begin{gathered}
\equiv \mathrm{S}-\mathrm{OH}+\mathrm{Fe}^{\mathrm{z}+} \rightarrow \equiv \mathrm{S}-\mathrm{OFe}^{(\mathrm{z}-1)}+\mathrm{H}^{+} \\
\equiv 2 \mathrm{~S}-\mathrm{OH}+\mathrm{Fe}^{\mathrm{z}+} \rightarrow \equiv(\mathrm{S}-\mathrm{OFe})_{2}{ }^{(\mathrm{z}-2)}+2 \mathrm{H}^{+} \\
\equiv \mathrm{S}-\mathrm{OH}+\mathrm{Fe}^{\mathrm{z}+}+\mathrm{H}_{2} \mathrm{O} \rightarrow \equiv \mathrm{S}-\mathrm{OFeOH}^{(\mathrm{z}-2)}+2 \mathrm{H}^{+}
\end{gathered}
$$

where: $\mathrm{S}$ is $\mathrm{Si}$ or $\mathrm{Al}$ and $\mathrm{Fe}^{\mathrm{z}+}$ are a Fe-hydroxyl species.

The purpose of the $\mathrm{NaOH}$ addition was to hydroxylate the sorbed Fe species since in the alkaline medium $\mathrm{Fe}(\mathrm{OH})_{4}{ }^{-}$species dominates. In this way, negative Fe oxo- and hydroxo-complexes are formed whose charge is compensated by sodium ions. Thus, beside zeolite - $\mathrm{SiOH}$ and -AlOH Brønsted acid sites, the negative surface charge increased due to the presence of additional -FeOH acid sites.

The measurement of the cation exchange capacity (CEC) of NZ and FeZ was conducted by standard US EPA SW-846 Method 9080 (1 M sodium acetate, $\mathrm{pH}=7$ ) [26]. The determined CEC value was $1.42 \mathrm{meq} / \mathrm{g}$ for NZ and $1.64 \mathrm{meq} / \mathrm{g}$ for FeZ, respectively.

Scanning electron microscopy (SEM) analysis and energy dispersive X-ray analysis (EDS) of saturated zeolites at different magnifications were performed using JEOL JSM 6490LV SEM coupled with an Oxford INCA EDS system, consisting of an Oxford INCA PentaFET3 Si(Li) detector and INCA Energy 350 processing software. The samples were coated with carbon to make them conductive. In addition, backscattered electrons mode (BSE) was used in order to distinguish newly-formed Hg-containing phases which appear brighter than others. 


\subsection{Sorption Experiments}

The salt, $\mathrm{Hg}\left(\mathrm{NO}_{3}\right)_{2} \cdot \mathrm{H}_{2} \mathrm{O}$, p.a. Kemika, was used for the preparation of stock solutions, from which the solutions of lower concentrations were prepared by dilution in ultrapure water. The $\mathrm{pH}$ of solutions was adjusted by adding a few drops of 0.1 or $1 \mathrm{~mol} / \mathrm{L} \mathrm{HNO}_{3}$. All experiments were performed in batch mode by using an incubator shaker at a room temperature of $25^{\circ} \mathrm{C}$. The concentration of $\mathrm{Hg}$ (II) before and after the performed experiments was determined by using Flame Atomic Absorption Spectrophotometer (PinAAcle 900F).

\subsection{Effect of $p H$}

The effect of the solution $\mathrm{pH}$ on the sorption efficiency of $\mathrm{Hg}$ (II) onto $\mathrm{NZ}$ and FeZ was studied in the narrow $\mathrm{pH}$ range of 2.09-2.30. The initial concentration of the $\mathrm{Hg}(\mathrm{II})$ solution was $4.006 \mathrm{mmol} / \mathrm{L}$. A total of $1.000 \mathrm{~g}$ of $\mathrm{NZ}$ or FeZ was mixed with $100 \mathrm{~mL}$ of the prepared $\mathrm{Hg}$ (II) solution during $24 \mathrm{~h}$ (solid/liquid ratio was $10 \mathrm{~g} / \mathrm{L}$ ) and at $230 \mathrm{rpm}$. After equilibration, the suspensions were filtered, the remaining concentration of $\mathrm{Hg}$ (II) was determined by atomic absorption spectrometry (AAS), and the equilibrium $\mathrm{pH}_{\mathrm{e}}$ was measured.

\subsection{Effect of Solid/Liquid Ratio}

The effect of the solid/liquid ratio, S/L, on the sorption efficiency of $\mathrm{Hg}(\mathrm{II})$ onto $\mathrm{NZ}$ and FeZ was performed at optimal $\mathrm{pH}=1.98$, determined on the basis of a previous experiment (effect of $\mathrm{pH}$ ). The initial concentrations of the $\mathrm{Hg}(\mathrm{II})$ solution was $4.056 \mathrm{mmol} / \mathrm{L}$.

Different mass of the NZ in the range of $0.2-3.6 \mathrm{~g}(\mathrm{~S} / \mathrm{L}=2,6,10,14,18,26,30,36 \mathrm{~g} / \mathrm{L})$ and FeZ in the range of $0.2-1.8 \mathrm{~g}(\mathrm{~S} / \mathrm{L}=2,6,10,14,18 \mathrm{~g} / \mathrm{L})$ was mixed with $100 \mathrm{~mL}$ of the prepared $\mathrm{Hg}(\mathrm{II})$ solution during $24 \mathrm{~h}$ and at $230 \mathrm{rpm}$. After equilibration, the suspensions were filtered and the concentration of $\mathrm{Hg}(\mathrm{II})$ in the equilibrium was determined by $\mathrm{AAS}$ and the equilibrium $\mathrm{pH}_{\mathrm{e}}$ was measured.

\subsection{Effect of Initial Concentration}

The effect of the initial concentration on the amount of sorbed $\mathrm{Hg}(\mathrm{II})$ per gram of $\mathrm{NZ}$ and FeZ as well as the sorption efficiency was performed at an optimal $\mathrm{pH} \approx 2.00$ and $\mathrm{S} / \mathrm{L}=10 \mathrm{~g} / \mathrm{L}$, determined on the basis of a previous experiments. The initial concentrations of solutions for the sorption of $\mathrm{Hg}$ (II) onto $\mathrm{NZ}$ and FeZ were in the range of $0.461-12.258 \mathrm{mmol} / \mathrm{L}$ and initial $\mathrm{pHs}$ of prepared solution were $1.99<\mathrm{pH}<2.01$. Therefore, $1.000 \mathrm{~g}$ of $\mathrm{NZ}$ or FeZ was mixed with $100 \mathrm{~mL}$ of $\mathrm{Hg}$ (II) solution during $24 \mathrm{~h}$ and at $230 \mathrm{rpm}$. After equilibration, the suspensions were filtered and the concentration of $\mathrm{Hg}$ (II) in the equilibrium was determined by $\mathrm{AAS}$ and the equilibrium $\mathrm{pH}_{\mathrm{e}}$ was measured. In addition, in all filtrates the concentration of released exchangeable cations $(\mathrm{Na}, \mathrm{K}, \mathrm{Ca}$, and $\mathrm{Mg}$ ) were determined by means of ion chromatography (Metrohm 761 Compact IC).

\subsection{Effect of Contact Time}

The effect of contact time on the amount of sorbed $\mathrm{Hg}$ (II) per gram of $\mathrm{NZ}$ and FeZ as well as sorption efficiency was performed at an optimal $\mathrm{pH} \approx 2.00$ and $\mathrm{S} / \mathrm{L}=10 \mathrm{~g} / \mathrm{L}$. The initial $\mathrm{Hg}(\mathrm{II})$ concentration of $7.917 \mathrm{mmol} \mathrm{L}$ with $\mathrm{pH}_{\mathrm{o}}=1.98$ for sorption onto $\mathrm{NZ}$ and $9.933 \mathrm{mmol} / \mathrm{L}$ with $\mathrm{pH}_{\mathrm{o}}=1.99$ for sorption onto FeZ were selected on the basis of the previous conducted experiments (effect of initial concentration) in order to achieve the maximum amount of sorbed $\mathrm{Hg}$ (II) onto NZ and FeZ. Experiments were conducted by mixing $20.000 \mathrm{~g}$ of $\mathrm{NZ}$ or FeZ with $2 \mathrm{~L}$ of prepared $\mathrm{Hg}$ (II) solution during $24 \mathrm{~h}$ and at $550 \mathrm{rpm}$. In the desired time interval, samples were collected, filtered, and the remaining concentrations of $\mathrm{Hg}(\mathrm{II})$ were determined by means of AAS and the equilibrium $\mathrm{pHs}$ were measured. The total sampling volume was less than $5-6 \%$ of the total solution volume. 


\subsection{Leaching Experiments}

The saturated samples from the previous experiment (effect of contact time) were collected, washed in ultrapure water, dried in order to examine their leaching properties, and marked as NZHg and FeZHg. The leaching of $\mathrm{Hg}$ (II) from saturated samples was examined according to the standard leaching method DIN 38414 [27] in ultrapure water in the wide $\mathrm{pH}$ range 2.00-12.05 adjusted by a small addition of $0.1 \mathrm{~mol} / \mathrm{L}$ of $\mathrm{HNO}_{3}$ or $0.1 \mathrm{~mol} / \mathrm{L}$ of $\mathrm{KOH}$. The mass of $1.000 \mathrm{~g}$ of $\mathrm{NZHg}$ or FeZHg was mixed with $10 \mathrm{~mL}$ of ultrapure water $(\mathrm{S} / \mathrm{L}=100)$ with different initial $\mathrm{pHs}$ over $24 \mathrm{~h}$ at $25 \mathrm{rpm}$ and $25^{\circ} \mathrm{C}$. After $24 \mathrm{~h}$ suspensions were filtered and the concentration of leached $\mathrm{Hg}$ (II) was determined in filtrates by using AAS, the final $\mathrm{pH}$ values of filtrates were also measured.

\subsection{Calculation of Characteristic Parameters}

The amount of $\mathrm{Hg}(\mathrm{II})$ sorbed on zeolite in time $\mathrm{t}(0 \mathrm{~h}<\mathrm{t}<24 \mathrm{~h}), \mathrm{q}_{\mathrm{t}}(\mathrm{mmol} / \mathrm{g})$ as well as the removal efficiency in time t expressed in percentage, $\alpha_{t}(\%)$, were calculated by Equations (4) and (5):

$$
\begin{aligned}
& q_{t}=\left(c_{o}-c_{t}\right) \cdot \frac{V}{m} \\
& \alpha_{t}=\frac{\left(c_{o}-c_{t}\right)}{c_{o}} \cdot 100
\end{aligned}
$$

where $c_{o}$ and $c_{t}$ are the concentrations of $\mathrm{Hg}(\mathrm{II})$ at $t=0$ and time $t(\mathrm{mmol} / \mathrm{L}), \mathrm{V}$ is the volume of the solution $(\mathrm{L})$, and $\mathrm{m}$ is the mass of zeolite $(\mathrm{g})$.

In the case when $t=24 \mathrm{~h}$ then $c_{t}=c_{e}, q_{t}=q_{e}$ and $\alpha_{t}=\alpha_{e}$ where $c_{e}$ is the concentration of $\mathrm{Hg}(\mathrm{II})$ in the equilibrium, $\mathrm{q}_{\mathrm{e}}$ is the experimentally observed amount of $\mathrm{Hg}$ (II) sorbed on zeolite in the equilibrium, and $\alpha_{\mathrm{e}}$ is the removal efficiency in equilibrium (\%).

The amount of $\mathrm{Hg}(\mathrm{II})$ leached from saturated zeolite, $\mathrm{q}_{\text {leach }}(\mathrm{mmol} / \mathrm{g})$ and the percentage of $\mathrm{Hg}$ (II) leached from saturated zeolite, $\alpha_{\text {leach }}(\%)$ were calculated by Equations (6) and (7):

$$
\begin{aligned}
& \mathrm{q}_{\text {leach }}=\mathrm{c}_{\text {leach }} \cdot \frac{\mathrm{V}}{\mathrm{m}} \\
& \alpha_{\text {leach }}=\frac{\mathrm{q}_{\text {leach }}}{\mathrm{q}_{\mathrm{e}}} \cdot 100
\end{aligned}
$$

where $c_{\text {leach }}$ is the concentration of the $\mathrm{Hg}(\mathrm{II})$ leached from zeolite $(\mathrm{mmol} / \mathrm{L})$.

\subsection{Modeling of Kinetic Data}

Different kinetic models are very useful for determining the rate controlling step in mass transfer during the sorption process. Two applied reaction kinetic models, Pseudo-first-order, PFO (Lagergen), and Pseudo-second-order, PSO (Ho), consider the chemical reaction to be a rate controlling step. The nonlinear equation of Pseudo-first-order is given by Equation (8) [28,29]:

$$
\mathrm{q}_{\mathrm{t}}=\mathrm{q}_{\mathrm{m}} \cdot\left(1-\mathrm{e}^{-\mathrm{k}_{1} \cdot \mathrm{t}}\right)
$$

where $\mathrm{q}_{\mathrm{m}}$ is the maximum sorption capacity obtained from the model $(\mathrm{mmol} / \mathrm{g})$ and $\mathrm{k}_{1}$ is the constant of the PFO (1/min).

The nonlinear form of the Pseudo-second-order is given by [28,29]:

$$
\mathrm{q}_{\mathrm{t}}=\frac{\mathrm{k}^{2} \cdot \mathrm{q}_{\mathrm{m}}^{2} \cdot \mathrm{t}}{1+\mathrm{k}_{2} \cdot \mathrm{q}_{\mathrm{m}} \cdot \mathrm{t}}
$$

in which $\mathrm{k}_{2}$ is the rate constant of the PSO $[\mathrm{g} /(\mathrm{mmol} \cdot \mathrm{min})]$. 
Sorption processes by using micro and mesoporous materials like natural zeolites are often limited by mass transfer due to the existence of cavities and pores inside the zeolite particle. In well-agitated systems, the diffusion of a substance from the bulk to the particle surface can be neglected, therefore the rate controlling step in the sorption process can be attributed to the film or intraparticle diffusion. Film or intraparticle diffusion control sorption rates can be established by applying different diffusion models.

Thus, the Bangham model suggests intraparticle diffusion as the only rate controlling step according to the equation in nonlinear form [30]:

$$
\mathrm{q}_{\mathrm{t}}=\frac{1}{\mathrm{~m}_{\mathrm{z}}} \cdot\left[\mathrm{c}_{\mathrm{o}}-\frac{\mathrm{c}_{\mathrm{o}}}{10^{\left(\frac{\mathrm{k}_{\mathrm{b}} \cdot \mathrm{m}_{\mathrm{z}}}{2 \cdot 303 \cdot \mathrm{v}}\right) \cdot \mathrm{t}_{\mathrm{b}}}}\right]
$$

where $m_{z}$ is the mass of sorbent per liter of solution $(g / L)$, while $k_{b}$ and $\alpha_{b}\left(\alpha_{b}<1\right)$ are the Bangham's constants.

Vermeulen's approximation also considers intraparticle diffusion as a rate controlling step and is given as follows [31]:

$$
\mathrm{q}_{\mathrm{t}}=\mathrm{q}_{\mathrm{m}} \cdot\left[1-\mathrm{e}^{\left(\frac{4 \cdot \mathrm{D}_{\mathrm{i}} \cdot \pi^{2} \cdot \mathrm{t}}{\mathrm{r}_{\mathrm{p}}^{2}}\right)}\right]
$$

where $D_{i}$ is the intraparticle diffusion coefficient $\left(\mathrm{cm}^{2} / \mathrm{min}\right)$ and $r_{p}$ is the sorbent particle radius $(\mathrm{cm})$.

The Weber-Morris model enables one to distinguish film diffusion from intraparticle diffusion by using linear Equation (12) [32]:

$$
\mathrm{q}_{\mathrm{t}}=\mathrm{k}_{\mathrm{WM}} \cdot \mathrm{t}^{1 / 2}+\mathrm{I}
$$

where $\mathrm{k}_{W M}$ is the Weber-Morris diffusion constant $\left[\mathrm{mmol} /\left(\mathrm{g} \cdot \mathrm{min}^{1 / 2}\right)\right]$ and I corresponds to the thickness of the boundary layer $(\mathrm{mmol} / \mathrm{g})$.

If $\mathrm{I}=0$ then the film diffusion is the only rate controlling step, otherwise both film and intraparticle diffusion could be considered. The proportion of film and intraparticle diffusion can be calculated according to Equation (13) [32]:

$$
\mathrm{RC}=\frac{\mathrm{I}}{\mathrm{q}_{\mathrm{e}}} \cdot 100
$$

where RC is the relative coefficient expressed in \%. Higher RC values indicate that film diffusion has a larger proportion in the overall mass transfer process.

Knowing the value of $\mathrm{k}_{\mathrm{WM}}$, the diffusion coefficient, $\mathrm{D}_{\mathrm{i}}$ can be calculated as follows:

$$
\mathrm{D}_{\mathrm{i}}=\pi \cdot\left(\frac{\mathrm{d}_{\mathrm{p}} \cdot \mathrm{k}_{\mathrm{WM}}}{12 \cdot \mathrm{q}_{\mathrm{e}}}\right)
$$

where $d_{p}$ is the particle diameter $(\mathrm{cm})$.

The double-exponential model (DEM) describes two-step sorption kinetic by non-linear equation [33]:

$$
\mathrm{q}_{\mathrm{t}}=\mathrm{q}_{\mathrm{m}}-\frac{\mathrm{B}_{1}}{\mathrm{~m}_{\mathrm{z}}} \cdot \mathrm{e}^{\left(-\mathrm{k}_{\mathrm{B}_{1}} \cdot \mathrm{t}\right)}-\frac{\mathrm{B}_{2}}{\mathrm{~m}_{\mathrm{z}}} \cdot \mathrm{e}^{\left(-\mathrm{k}_{\mathrm{B}_{2}} \cdot \mathrm{t}\right)}
$$

where $B_{1}$ and $B_{2}$ are the sorbed concentration of sorbate in the rapid and slow step $(\mathrm{mmol} / \mathrm{L})$ while $k_{B 1}$ and $\mathrm{k}_{\mathrm{B} 2}$ are the rapid and slow rate constants $(1 / \mathrm{min})$.

The overall sorption rate, $r$ in $[\mathrm{mmol} /(\mathrm{g} \cdot \mathrm{min})]$ is a sum of the rapid, $r_{1}$ and slow, $r_{2}$ steps [33]:

$$
\mathrm{r}=\mathrm{r}_{1}+\mathrm{r}_{2}=\frac{\mathrm{B}_{1}}{\mathrm{~m}_{\mathrm{z}}} \cdot \mathrm{k}_{\mathrm{B}_{1}}+\frac{\mathrm{B}_{2}}{\mathrm{~m}_{\mathrm{z}}} \cdot \mathrm{k}_{\mathrm{B}_{2}}
$$


In addition, the percentage of sorbed in rapid (RF) and in slow (SF) steps can be calculated as follows [33]:

$$
\begin{aligned}
& \mathrm{RF}=\left(\frac{\mathrm{B}_{1}}{\mathrm{~B}_{1}+\mathrm{B}_{2}}\right) \cdot 100 \\
& \mathrm{SF}=\left(\frac{\mathrm{B}_{2}}{\mathrm{~B}_{1}+\mathrm{B}_{2}}\right) \cdot 100
\end{aligned}
$$

For modeling sorption kinetic data by non-linear regression analysis, the Mathcad 14 software was used. Non-linear regression analysis was applied because using the original equation achieves greater accuracy than by transforming the equation into a linear form [34]. The agreement of the experimental data modeled by linear regression analysis was estimated using the linear regression coefficient, $\mathrm{R}^{2}$ while modeled by non-linear regression analysis was evaluated using the non-linear regression coefficient, $\mathrm{r}^{2}$, as well as two error functions, non-linear chi-square test $\left(\chi^{2}\right)$ and root mean square error (RMSE) [35]:

$$
\begin{aligned}
x^{2} & =\sum_{i=1}^{n} \frac{\left(q_{m}-q_{e}\right)^{2}}{q_{m}} \\
\text { RMSE } & =\sqrt{\sum_{i=1}^{n} \frac{\left(q_{m}-q_{e}\right)^{2}}{n}}
\end{aligned}
$$

Smaller values of error functions are an indicator of better agreement of predicted values, $\mathrm{q}_{\mathrm{m}}$ with experimentally determined ones, $\mathrm{q}_{\mathrm{e}}$.

\section{Results and Discussion}

\subsection{Effect of $p H$}

The $\mathrm{pH}$ of the suspension is one of the most important parameters that affect the sorbent surface charge as well as type of metal species. Figure 1 illustrates the distribution of mercury species in relation with $\mathrm{pH}$ based on the hydrolysis constants represented by Equations (21)-(23) [36,37]:

$$
\begin{array}{ll}
\mathrm{Hg}^{2+}+\mathrm{H}_{2} \mathrm{O} \rightleftarrows \mathrm{HgOH}^{+}+\mathrm{H}^{+} & \mathrm{pK}_{1}=3.40 \\
\mathrm{Hg}^{2+}+2 \mathrm{H}_{2} \mathrm{O} \rightleftarrows \mathrm{Hg}(\mathrm{OH})_{2}+2 \mathrm{H}^{+} & \mathrm{pK}_{2}=5.98 \\
\mathrm{Hg}^{2+}+3 \mathrm{H}_{2} \mathrm{O} \rightleftarrows \mathrm{Hg}(\mathrm{OH})_{3}^{-}+3 \mathrm{H}^{+} & \mathrm{pK}_{3}=21.1
\end{array}
$$

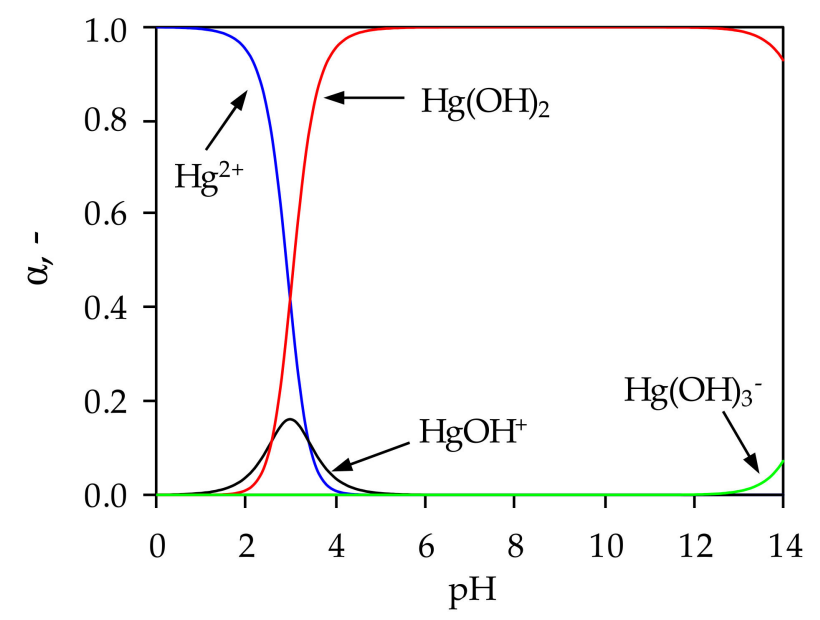

Figure 1. Distribution of $\mathrm{Hg}(\mathrm{II})$ species as a function of $\mathrm{pH}$. 
From Figure 1 it is clear that below $\mathrm{pH}=2.9$ the dominant species is $\mathrm{Hg}^{2+}$, the $\mathrm{HgOH}^{+}$species exists in the range $1.5<\mathrm{pH}<4.5$, while $\mathrm{Hg}(\mathrm{OH})_{3}{ }^{-}$appears at $\mathrm{pH}>13.2$. Precipitation of $\mathrm{Hg}(\mathrm{II})$ begins at $\mathrm{pH}=2.4$, and the proportion of $\mathrm{Hg}(\mathrm{OH})_{2}$ increases with a further increase in $\mathrm{pH}$, and $\mathrm{pH}$ range $4.7<\mathrm{pH}<13.2 \mathrm{Hg}$ (II) exists completely in the form of $\mathrm{Hg}(\mathrm{OH})_{2}$. This suggests that the mercury sorption would take place in a very narrow $\mathrm{pH}$ range if the influence of precipitation is to be completely excluded.

For this reason, sorption experiments were not performed above $\mathrm{pH}=2.4$ and below $\mathrm{pH}=2$ due to degradation and dissolution of the zeolite structure. In order to determine the optimal $\mathrm{pH}$ for $\mathrm{Hg}$ (II) sorption onto $\mathrm{NZ}$ and $\mathrm{FeZ}$, it was necessary to calculate the $\mathrm{pH}$ value at which precipitation starts to occur $\left(\mathrm{pH}_{\mathrm{ppt}}\right)$. The $\mathrm{pH}_{\mathrm{ppt}}$ values depend on the mercury solubility product constant, $\mathrm{K}_{\mathrm{sp}}=3.2 \times 10^{-26}$ and the initial mercury concentration according to Equation $(24)[37,38]$ :

$$
\mathrm{pH}_{\mathrm{ppt}}=14-\log \sqrt{\frac{\mathrm{c}_{\mathrm{o}}\left(\mathrm{Hg}^{2+}\right)}{\mathrm{K}_{\mathrm{sp}}\left[\mathrm{Hg}(\mathrm{OH})_{2}\right]}}
$$

The measured $\mathrm{pH}_{\mathrm{e}}$ and calculated $\mathrm{pH}_{\mathrm{ppt}}$ values for the given initial $\mathrm{Hg}$ (II) concentration as well as removal efficiency, $\alpha$ as a function of $\mathrm{pH}_{\mathrm{o}}$ are shown in Figure 2a,b.

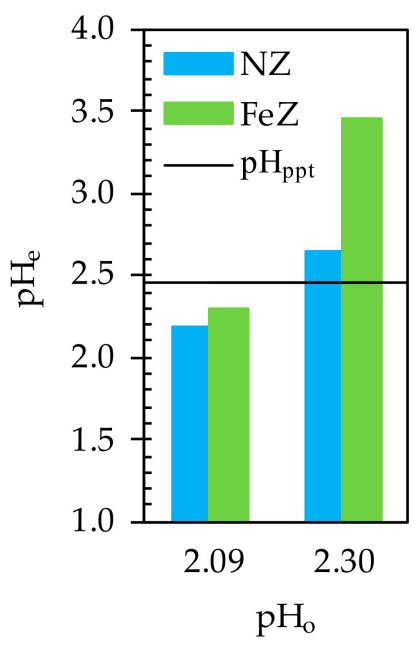

(a)

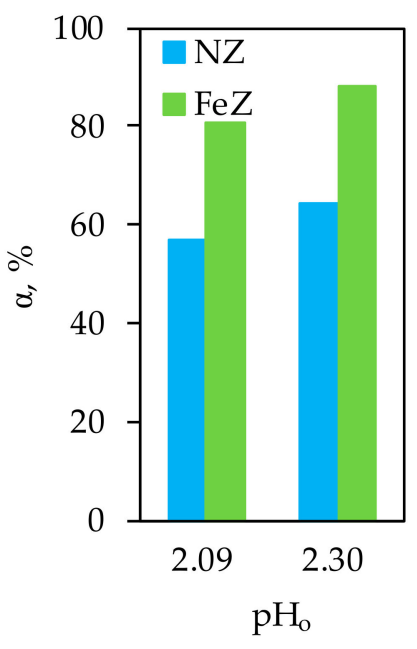

(b)

Figure 2. (a) $\mathrm{pH}_{\mathrm{e}}$ vs. $\mathrm{pH}_{\mathrm{o}}$ after sorption of $\mathrm{Hg}$ (II) onto $\mathrm{NZ}$ and FeZ. (b) The effect of $\mathrm{pH}_{\mathrm{o}}$ on removal efficiency, $\alpha$ of $\mathrm{Hg}(\mathrm{II})$ onto $\mathrm{NZ}$ and FeZ.

At $\mathrm{pH}_{\mathrm{o}}=2.30$ in Figure 2a, the $\mathrm{pH}_{\mathrm{e}}$ values for both $\mathrm{NZ}$ and FeZ are above the calculated $\mathrm{pH}_{\mathrm{ppt}}$ which confirms that the precipitation of mercury in the form of hydroxide occurs in the solution while at $\mathrm{pH}_{\mathrm{o}}=2.09$ precipitation is excluded. Therefore, $\mathrm{pH}_{\mathrm{o}}=2.09$ is selected as the optimal $\mathrm{pH}$ for $\mathrm{Hg}$ (II) sorption onto NZ and FeZ, at which the obtained efficiency is $57 \%$ for NZ and $81 \%$ for FeZ (Figure $2 b$ ).

\subsection{Effect of $S / L$ Ratio}

The determination of the optimal S/L ratio is also an important parameter that needs to be considered in the design of sorption processes. Dependence of the removal efficiency, $\alpha$ of $\mathrm{Hg}$ (II) sorption onto NZ and FeZ for different solid/liquid (S/L) ratios is shown in Figure 3. 


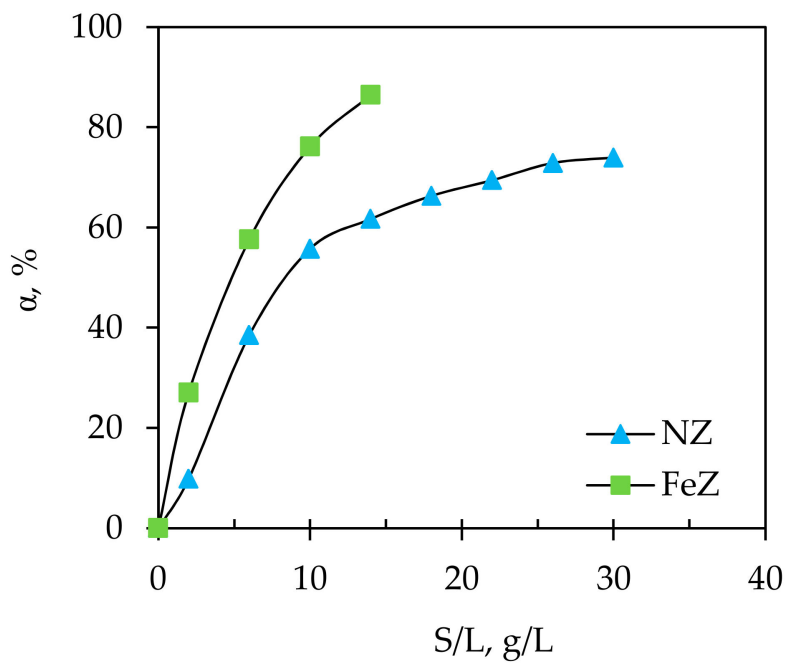

Figure 3. The effect of solid/liquid ratio (S/L) ratio on removal efficiency, $\alpha$ of $\mathrm{Hg}$ (II) onto $\mathrm{NZ}$ and FeZ.

Firstly, a rapid and then gradual increase in $\alpha$ values for NZ were observed with plateau reached at $\mathrm{S} / \mathrm{L}>26 \mathrm{~g} / \mathrm{L}$. For FeZ, the increase in $\alpha$ was rapid, but without achieving plateau since above $\mathrm{S} / \mathrm{L}=18 \mathrm{~g} / \mathrm{L}$, precipitation occurs and the measured equilibrium $\mathrm{pH}$ was higher than the calculated $\mathrm{pH}_{\mathrm{ppt}}$. The increase in removal efficiency is connected with a higher mass of zeolite in the same volume of suspension, i.e., an increase in the number of available active sorption sites. Although higher S/L ratios give better removal efficiency, they also cause an increase in the $\mathrm{pH}$ of the suspension which can lead to mercury precipitation. For an initial $\mathrm{Hg}$ (II) concentration of $4.056 \mathrm{mmol} / \mathrm{L}$ used in this experiment, the $\mathrm{pH}_{\mathrm{ppt}}$ value calculated by Equation (30) is compared in Figure 4 with the $\mathrm{pH}_{\mathrm{e}}$ after the sorption of $\mathrm{Hg}(\mathrm{II})$ onto $\mathrm{NZ}$ and $\mathrm{FeZ}$ at different $\mathrm{S} / \mathrm{L}$ ratios.

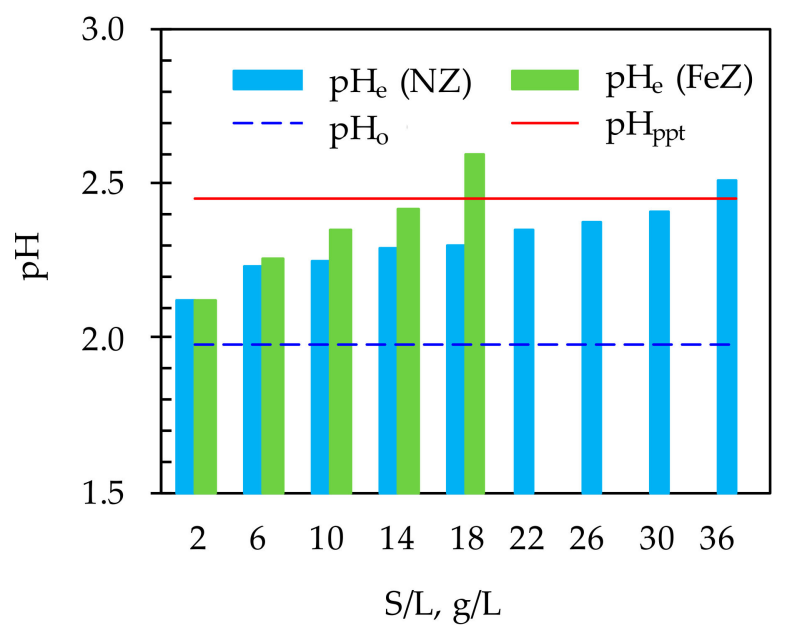

Figure 4. Comparison of $\mathrm{pH}_{\mathrm{e}}$ with $\mathrm{pH}_{\mathrm{ppt}}$ and $\mathrm{pH}_{\mathrm{o}}$ after the sorption of $\mathrm{Hg}(\mathrm{II})$ onto $\mathrm{NZ}$ and $\mathrm{FeZ}$ at different $\mathrm{S} / \mathrm{L}$ ratios.

As the $\mathrm{S} / \mathrm{L}$ ratio increases, the equilibrium $\mathrm{pH}_{\mathrm{e}}$ of the suspensions also increase. The increase in $\mathrm{pH}$ is due to both effects of mercury sorption on zeolites and the exchange of $\mathrm{H}^{+}$with exchangeable cations. At $\mathrm{S} / \mathrm{L}=18 \mathrm{~g} / \mathrm{L}$ for FeZ and $\mathrm{S} / \mathrm{L}=36 \mathrm{~g} / \mathrm{L}$ for NZ, mercury precipitation was observed since the measured equilibrium $\mathrm{pH}_{\mathrm{e}}$ of the suspensions was higher than the calculated $\mathrm{pH}_{\mathrm{ppt}}$. This indicates that determining the optimal $\mathrm{S} / \mathrm{L}$ ratio is one of the key parameters in order to avoid precipitation with achieving maximum efficiency by using a minimum dose of zeolite. 
Therefore, according to Figure 3, at a given experimental condition, the maximum removal efficiency of $74 \%$ for $\mathrm{NZ}$ is achieved at $\mathrm{S} / \mathrm{L}=30 \mathrm{~g} / \mathrm{L}$ while for $\mathrm{FeZ}$ this value was $87 \%$ at $\mathrm{S} / \mathrm{L}=14 \mathrm{~g} / \mathrm{L}$. This indicates that even with twice higher amount of $\mathrm{NZ}$ compared to FeZ, the same efficiency is not achieved, which justifies the natural zeolite modification process. Taking into account the S/L ratio at which mercury precipitate in suspension with FeZ, the $\mathrm{S} / \mathrm{L}$ ratio of $10 \mathrm{~g} / \mathrm{L}$ is selected as optimal since at $\mathrm{S} / \mathrm{L}=14 \mathrm{~g} / \mathrm{L}$ the $\mathrm{pH}_{\text {ppt }}$ is very close to the conditions under which precipitation occurs. In order to compare the results with FeZ, further experiments on NZ were conducted at the same $\mathrm{S} / \mathrm{L}=10 \mathrm{~g} / \mathrm{L}$.

\subsection{Effect of Contact Time}

It is important to know the minimum contact time required to achieve maximum sorbent removal efficiency in the shortest possible time. The effect of contact time on the amount of $\mathrm{Hg}$ (II) sorbed on $\mathrm{NZ}$ and FeZ as well as the removal efficiency is presented in Figure 5.

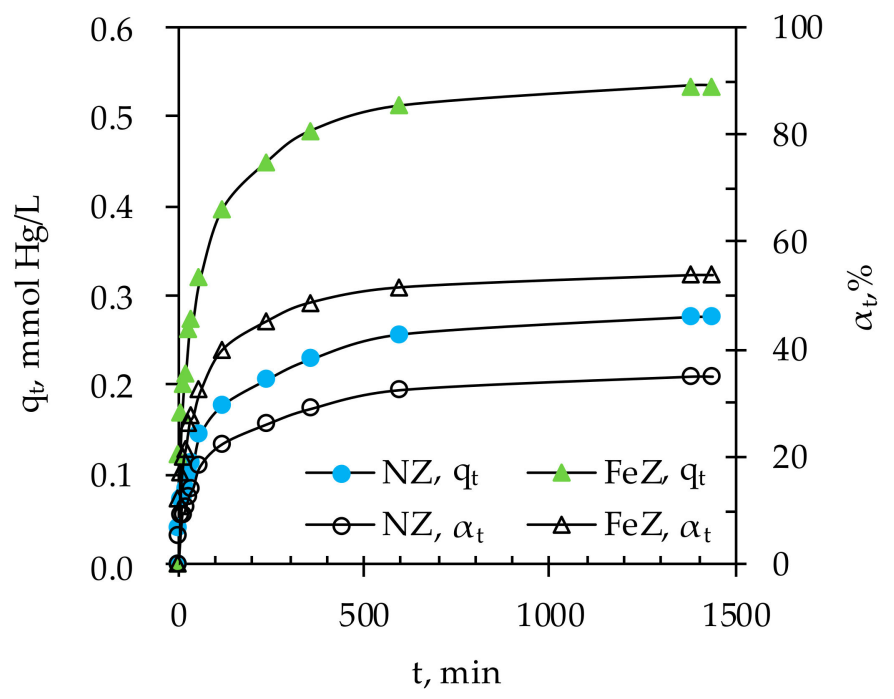

Figure 5. The amount of $\mathrm{Hg}(\mathrm{II})$ sorbed on $\mathrm{NZ}$ and $\mathrm{FeZ}$ as well as the removal efficiency in relation to contact time.

The results show that sorption of $\mathrm{Hg}(\mathrm{II})$ onto both $\mathrm{NZ}$ and FeZ takes place in two stages, the initial stage within 240 min accompanied by rapid increases in $\mathrm{q}_{\mathrm{t}}$ and $\alpha_{\mathrm{t}}$, followed by a second stage with a gradual increase in $\mathrm{q}_{t}$ and $\alpha_{\mathrm{t}}$ until equilibrium is reached. The observed two sorption stages suggest that the initial sorption is rapid due to the readily available active sorption sites, and becomes slower as a consequence of $\mathrm{Hg}$ (II) sorption at less available sites. A minimum contact time of $600 \mathrm{~min}$ is required to achieve a maximum removal efficiency of $35 \%$ or $0.28 \mathrm{mmol} \mathrm{Hg} / \mathrm{g}$ of $\mathrm{NZ}$ and $54 \%$ or $0.53 \mathrm{mmol} \mathrm{Hg} / \mathrm{g}$ of FeZ for the given experimental conditions. Under the used experimental conditions, precipitation of $\mathrm{Hg}(\mathrm{II})$ was not possible since the measured $\mathrm{pH}_{\mathrm{e}}$ was lower than the calculated $\mathrm{pH}_{\mathrm{ptt}}$ (results are not shown here).

The existence of two stages during the sorption of $\mathrm{Hg}(\mathrm{II})$ indicates a possible change in the sorption mechanism that can be established by determining the sorption rate controlling step. For this purpose, two reactions (Pseudo-first-order, Pseudo-second-order) and four diffusions (Bangham, Vermeulen's approximation, Weber-Morris, and Double-exponential) kinetic models were applied on kinetic sorption data.

For all applied models, specific parameters are obtained by nonlinear regression analysis except with the Weber-Morris model. Calculated parameters are summarized in Table 1 and fitting of experimental points with models are presented in Figure 6a,b.

By comparing regression coefficient as well as values of RMSE and $\chi^{2}$ for PFO and PSO, results suggest that the PSO is better applicable to experimental results for NZ and FeZ. However, 
since the values of $\mathrm{q}_{\mathrm{e}}$ differ from those obtained from the model, $\mathrm{q}_{\mathrm{m}}$ it indicates that rather film or intraparticle diffusion could be the rate controlling step.

Therefore, the kinetic results were processed using the Bangham model. Although the correlation indicators are satisfactory, the curve that describe this model (Figure 6a) indicates that this model does not fit well enough with the experimental results, which confirms that intraparticle diffusion is not the only rate controlling step.

Table 1. Kinetic models constantss and error analysis for $\mathrm{Hg}(\mathrm{II})$ sorption onto NZ and FeZ.

\begin{tabular}{|c|c|c|c|}
\hline \multirow{2}{*}{ Kinetic Model } & Parameters & NZ & $\mathrm{FeZ}$ \\
\hline & $\mathrm{q}_{\mathrm{e}}(\mathrm{mmol} / \mathrm{g})$ & 0.277 & 0.534 \\
\hline \multirow{5}{*}{ Pseudo-first-order model (PFO) } & $\mathrm{q}_{\mathrm{m}}(\mathrm{mmol} / \mathrm{g})$ & 0.248 & 0.488 \\
\hline & $\mathrm{k}_{1}(1 / \mathrm{min})$ & 0.016 & 0.025 \\
\hline & $\mathrm{r}^{2}$ & 0.945 & 0.943 \\
\hline & RMSE & 0.019 & 0.046 \\
\hline & $x^{2}$ & $2.205 \times 10^{-3}$ & $4.358 \times 10^{-3}$ \\
\hline \multirow{5}{*}{ Pseudo-second-order model (PSO) } & $\mathrm{q}_{\mathrm{m}}(\mathrm{mmol} / \mathrm{g})$ & 0.268 & 0.526 \\
\hline & $\mathrm{k}_{2}[\mathrm{~g} /(\mathrm{mmol} \cdot \mathrm{min})]$ & 0.073 & 0.064 \\
\hline & $\mathrm{r}^{2}$ & 0.981 & 0.982 \\
\hline & RMSE & 0.014 & 0.025 \\
\hline & $x^{2}$ & $6.697 \times 10^{-4}$ & $6.923 \times 10^{-4}$ \\
\hline \multirow{5}{*}{ Bangham model } & $\alpha$ & 0.300 & 0.275 \\
\hline & $\mathrm{k}_{\mathrm{b}}$ & 0.005 & 0.012 \\
\hline & $\mathrm{r}^{2}$ & 0.974 & 0.970 \\
\hline & RMSE & 0.015 & 0.032 \\
\hline & $x^{2}$ & $1.060 \times 10^{-3}$ & $4.225 \times 10^{-3}$ \\
\hline \multirow{5}{*}{ Vermeulen's approximation } & $\mathrm{q}_{\mathrm{m}}(\mathrm{mmol} / \mathrm{g})$ & 0.277 & 0.534 \\
\hline & $\mathrm{D}_{\mathrm{i}} \times 10^{7}\left(\mathrm{~cm}^{2} / \mathrm{min}\right)$ & 5.391 & 9.532 \\
\hline & $\mathrm{r}^{2}$ & 0.993 & 0.993 \\
\hline & RMSE & 0.185 & 0.387 \\
\hline & $x^{2}$ & $12.102 \times 10^{-2}$ & $10.102 \times 10^{-2}$ \\
\hline \multirow{8}{*}{ Weber-Morris intra-particle diffusion model } & $\mathrm{k}_{\mathrm{WM} 1}\left[\mathrm{mmol} /\left(\mathrm{g} \cdot \mathrm{min}^{1 / 2}\right)\right]$ & 0.017 & 0.034 \\
\hline & $\mathrm{D}_{\mathrm{i} 1} \times 10^{7}\left(\mathrm{~cm}^{2} / \mathrm{min}\right)$ & 4.165 & 4.632 \\
\hline & $\mathrm{I}(\mathrm{mmol} / \mathrm{g})$ & 0.087 & 0.056 \\
\hline & $\mathrm{RC}(\%)$ & 3.140 & 10.426 \\
\hline & $\mathrm{R}^{2}$ & 0.973 & 0.984 \\
\hline & $\mathrm{k}_{\mathrm{WM} 2}\left[\mathrm{mmol} /\left(\mathrm{g} \cdot \mathrm{min}^{1 / 2}\right)\right]$ & 0.007 & 0.008 \\
\hline & $\mathrm{D}_{\mathrm{i} 2} \times 10^{8}\left(\mathrm{~cm}^{2} / \mathrm{min}\right)$ & 5.879 & 2.642 \\
\hline & $\mathrm{R}^{2}$ & 0.986 & 0.960 \\
\hline \multirow{13}{*}{ Double-exponential model } & $\mathrm{qm}_{\mathrm{m}}(\mathrm{mmol} / \mathrm{g})$ & 0.277 & 0.526 \\
\hline & $\mathrm{k}_{\mathrm{B} 1} \times 10^{3}(1 / \mathrm{min})$ & 59.000 & 127.000 \\
\hline & $\mathrm{B}_{1}(\mathrm{mmol} / \mathrm{L})$ & 1.006 & 1.997 \\
\hline & $\mathrm{k}_{\mathrm{B} 2} \times 10^{3}(1 / \mathrm{min})$ & 3.738 & 6.644 \\
\hline & $\mathrm{B}_{2}(\mathrm{mmol} / \mathrm{L})$ & 1.683 & 3.212 \\
\hline & $\mathrm{r}_{1} \times 10^{3}[\mathrm{mmol} /(\mathrm{g} \cdot \mathrm{min})]$ & 214.000 & 501.000 \\
\hline & $\mathrm{r}_{2} \times 10^{3}\left[\mathrm{mmol} /\left(\mathrm{g} \cdot \mathrm{min}^{1 / 2}\right)\right]$ & 1.356 & 3.768 \\
\hline & $\mathrm{r} \times 10^{3}\left[\mathrm{mmol} /\left(\mathrm{g} \cdot \mathrm{min}^{1 / 2}\right)\right]$ & 215.356 & 504.768 \\
\hline & $\mathrm{RF}(\%)$ & 31.41 & 38.34 \\
\hline & SF $(\%)$ & 62.59 & 61.66 \\
\hline & $r^{2}$ & 0.994 & 0.996 \\
\hline & RMSE & 0.007 & 0.011 \\
\hline & $x^{2}$ & $7.194 \times 10^{-6}$ & $1.306 \times 10^{-4}$ \\
\hline
\end{tabular}




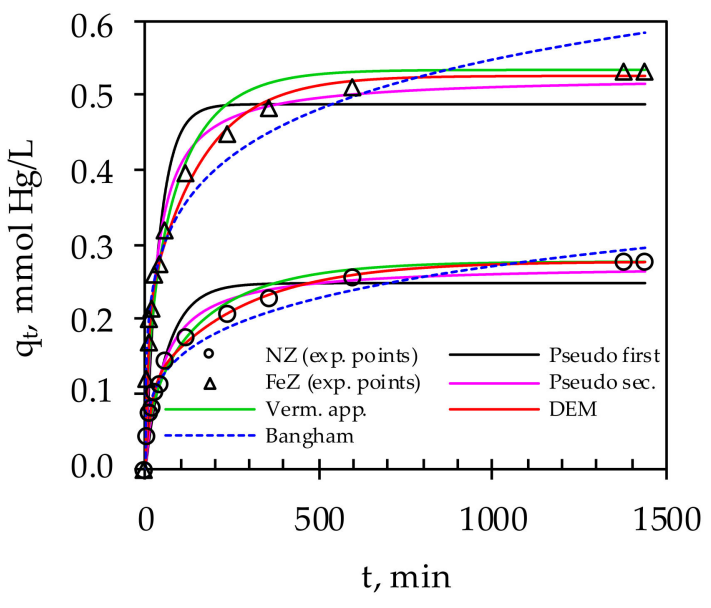

(a)

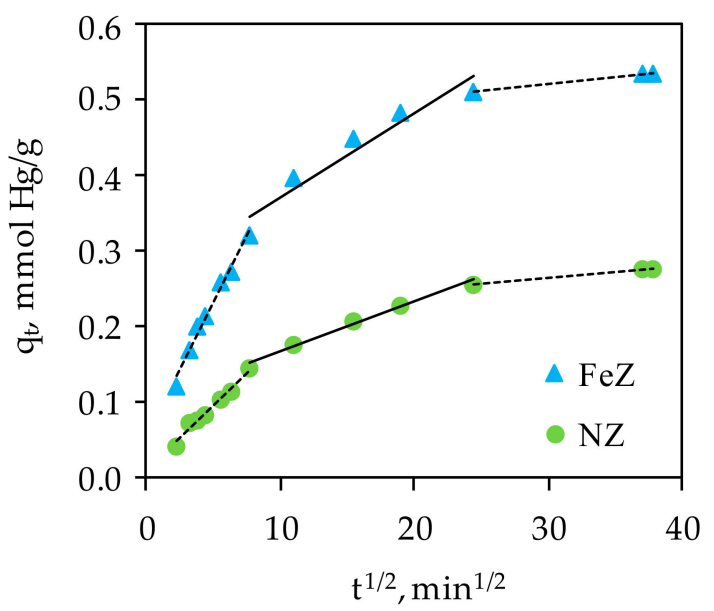

(b)

Figure 6. (a) Fitting of experimental data with Pseudo-first-order model (PFO), Pseudo-second-order (PSO), Vermeulen's approximation, double-exponential model (DEM), and the Bangham model.

(b) Fitting of experimental data with the Weber-Morris model.

Furthermore, the application of the Vermenulen's approximation shows good fitting in the whole observed time interval (Figure 6a) which confirms the similarity of $\mathrm{q}_{\mathrm{e}}$ and $\mathrm{q}_{\mathrm{m}}$ as well as $\mathrm{r}^{2}$. From the above, it could be concluded that intraparticle diffusion is the only rate controlling step. However, the values of the agreement indicators, RMSE and $\chi^{2}$, are the highest in comparison with all other tested models. Therefore, two other models have been applied that should provide to define the rate controlling step of $\mathrm{Hg}$ (II) sorption onto $\mathrm{NZ}$ and FeZ.

In this light, the experimental data were processed using the Weber-Morris model and the graphical plot $q_{t}$ vs. $t^{1 / 2}$ is shown in Figure $6 b$. Since the plot shows multilinearity over the entire duration of the sorption process with satisfactory values of regression coefficients for each stages, this indicates that both film and intraparticle diffusion are involved in $\mathrm{Hg}$ (II) sorption on $\mathrm{NZ}$ and $\mathrm{FeZ}$ $(\mathrm{I}>0)$. In order to better understand which mechanism is more dominant, the results shown in Table 1 confirm that $k_{W M 1}>k_{W M 2}$, as well as $D_{i 1}>D_{i 2}$, which confirms that the intraparticle diffusion is the rate controlling step. This is supported by the calculated relative coefficient (RC), which indicates that the contribution of the film diffusion is only $3 \%$ for $\mathrm{NZ}$ and $10 \%$ for FeZ.

The existence of two stages of $\mathrm{Hg}$ (II) sorption onto $\mathrm{NZ}$ and $\mathrm{FeZ}$ was also confirmed by applying the Double-exponential model. Calculated parameters $k_{b 1}>k_{b 2}, B_{1}>B_{2}$ as well as $r_{1}>r_{2}$, for both NZ and $\mathrm{FeZ}$ indicate faster sorption of $\mathrm{Hg}$ (II) in the first stages controlled by film diffusion than that in second stage which is controlled by intraparticle diffusion. Furthermore, the mentioned constants $\left(\mathrm{k}_{\mathrm{b} 1}, \mathrm{k}_{\mathrm{b} 2}, \mathrm{~B}_{1}, \mathrm{~B}_{2}\right)$ are almost doubly higher in the case of FeZ compared with NZ, which is a consequence of more available active sites in FeZ due to modification. These observations are consistent with the obtained sorption capacities (Figure 5). The number of readily available active sites is higher at the beginning, in the faster stage of the process, indicating that sorption in the second stage of the process takes place inside the structure of the zeolite particle. The values of RF and SF for both NZ and FeZ indicate that the major $\mathrm{Hg}(\mathrm{II})$ is sorbed at a slower stage which is controlled by intraparticle diffusion. In comparison with other models, Double-exponential model shows the best fitting with experimental results based on the highest obtained value of $r^{2}$ and the smallest values of RMSE, $\chi^{2}$, as well as the identical value of $\mathrm{q}_{\mathrm{e}}$ and $\mathrm{q}_{\mathrm{m}}$. Based on this, the main mechanism of mass transfer is intraparticle diffusion, accompanied by film diffusion. 


\subsection{Effect of Initial Concentration}

An examination of the effect of the initial concentration makes it possible to determine the concentration range of the contaminant in which the zeolite shows the effective sorption capacity for the given experimental conditions. The influence of initial $\mathrm{Hg}$ (II) concentration on the amount of $\mathrm{Hg}(\mathrm{II})$ sorbed per gram of NZ and FeZ, as well as on removal efficiency is presented in Figure 7a,b.

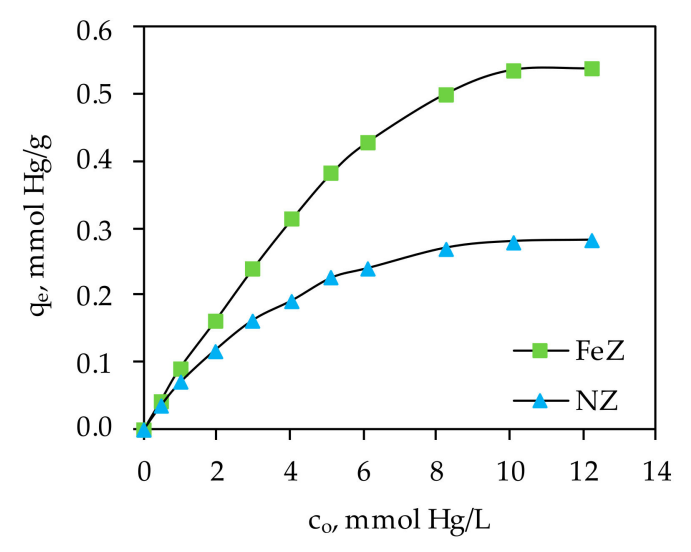

(a)

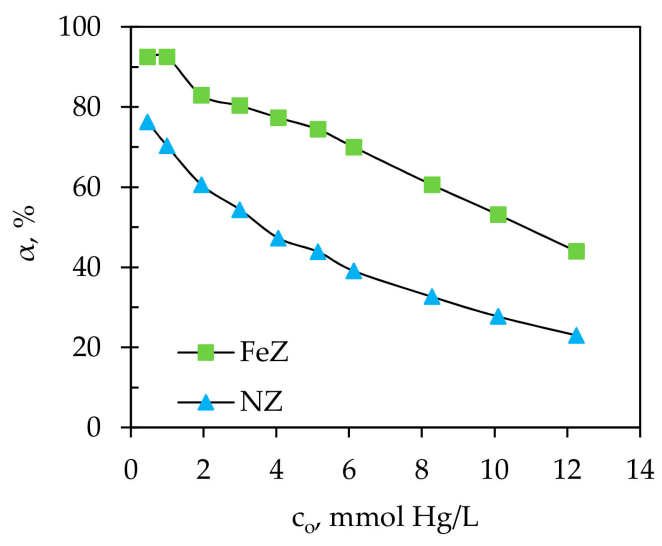

(b)

Figure 7. (a) The amount of $\mathrm{Hg}(\mathrm{II})$ sorbed per gram of $\mathrm{NZ}$ and $\mathrm{FeZ}$ vs. $\mathrm{c}_{\mathrm{o}}$ and (b) the removal efficiency of $\mathrm{Hg}(\mathrm{II})$ vs. $\mathrm{c}_{\mathrm{o}}$.

An almost linear increase in $\mathrm{q}_{\mathrm{e}}$ was observed with an increase in initial concentration up to $6 \mathrm{mmol} / \mathrm{L}$ for FeZ while an increase in $\mathrm{q}_{\mathrm{e}}$ for $\mathrm{NZ}$ was gradual in the whole range of investigated initial concentrations. It can also be noted that for $\mathrm{c}_{\mathrm{o}}>8 \mathrm{mmol} \mathrm{Hg} / \mathrm{L}$ for $\mathrm{NZ}$ and $\mathrm{c}_{\mathrm{o}}>10 \mathrm{mmol} \mathrm{Hg} / \mathrm{L}$ for $\mathrm{FeZ}$ there is no further increase in $\mathrm{q}_{\mathrm{e}}$ with the increase initial $\mathrm{Hg}$ (II) concentration since all available sorption sites are saturated. This indicates that $\mathrm{NZ}$ is effective for $\mathrm{Hg}$ (II) concentrations up to $8 \mathrm{mmol} / \mathrm{L}$ while $\mathrm{FeZ}$ up to $10 \mathrm{mmol} / \mathrm{L}$. According to Figure $7 \mathrm{a}$, the maximum amount of sorbed $\mathrm{Hg}$ (II) was achieved by establishing plateau and equals $0.28 \mathrm{mmol}$ of $\mathrm{Hg} / \mathrm{g}$ for $\mathrm{NZ}$ and $0.54 \mathrm{mmol}$ of $\mathrm{Hg} / \mathrm{g}$ for FeZ.

When analyzing the removal efficiency in Figure $7 \mathrm{~b}$, a decreasing trend can be noticed with an increase in initial $\mathrm{Hg}$ (II) concentration, i.e., the highest removal efficiencies of $76 \%$ for $\mathrm{NZ}$ and $92 \%$ for FeZ are obtained for the lowest initial concentration of $0.47 \mathrm{mmol} \mathrm{Hg} / \mathrm{L}$. Significant efficacy observed for $\mathrm{FeZ}$, especially for low $\mathrm{Hg}$ (II) concentrations makes it a very promising sorbent for the remediation of a mercury contaminated environment.

The almost double amount of $\mathrm{Hg}$ (II) sorbed per gram of FeZ relative to $\mathrm{NZ}$ is due to a modification that caused an increase in the amount of iron content as well as the net negative surface charge of the zeolite particle which is compensated by the presence of exchangeable alkali and alkaline earth cations, among which sodium dominates [21]. The Figure 8 shows relationships between in-going $\mathrm{Hg}$ (II) ions and out-going zeolite exchangeable cations $\left(\mathrm{Na}, \mathrm{K}, \mathrm{Ca}\right.$, and $\mathrm{Mg}$ ) as well as $\mathrm{pH}_{\mathrm{e}}$ in the function of initial $\mathrm{Hg}$ (II) concentration.

The results show almost a twice total released concentration of exchangeable cations from FeZ than from NZ, which can be attributed to twice the amount of $\mathrm{Hg}$ (II) sorbed onto FeZ compared to NZ. The main exchangeable cation was Na for FeZ while for NZ, it was Ca. For both zeolite samples, a nonstoichiometric relationship between the released exchangeable cations and sorbed $\mathrm{Hg}$ (II) was observed. The reason for that could be attributed to the very low initial $\mathrm{pH}$ values $\left(1.99<\mathrm{pH}_{\mathrm{o}}<2.01\right)$ of $\mathrm{Hg}$ (II) solutions with an extremely high concentration of $\mathrm{H}^{+}$ions, which are easily exchangeable with cations from the zeolite structure. However, with an increase in the initial concentration of $\mathrm{Hg}$ (II) for both zeolite, the competition effect is less pronounced, since the difference between the amount of released exchangeable cations and the sorbed $\mathrm{Hg}$ (II) decreases. This is supported by the results of $\mathrm{pH}_{\mathrm{e}}$ measurements, which decrease with increasing initial $\mathrm{Hg}$ (II) concentration, where the maximum 
measured $\mathrm{pHe}$ was lower than the calculated $\mathrm{pH}_{\mathrm{ptt}}$ value. Smaller increase in $\mathrm{pH}$ observed for $\mathrm{NZ}$ was due to the release of dominant $\mathrm{Ca}$, which shows a hydrolyzing effect [21].
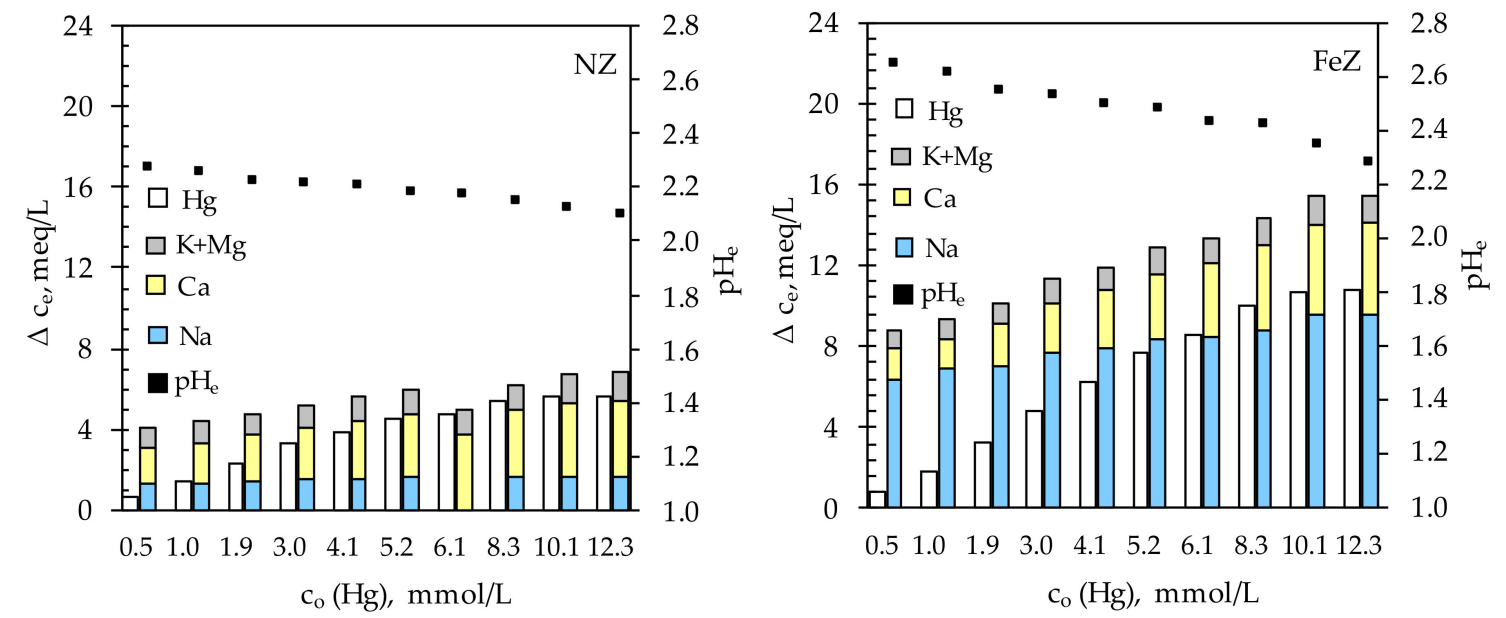

Figure 8. The relation between sorbed $\mathrm{Hg}(\mathrm{II})$ ions and released exchangeable cations and $\mathrm{pH}_{\mathrm{e}}$ in function of initial $\mathrm{Hg}(\mathrm{II})$ concentration.

When comparing the CEC values for NZ (1.42 meq/g) and for FeZ (1.64 meq/g), it was observed that the zeolites are not completely saturated with $\mathrm{Hg}$ (II) since the maximum amount of sorbed $\mathrm{Hg}(\mathrm{II})$ expressed in meq/g is 0.56 for $\mathrm{NZ}$ and 1.08 for FeZ, respectively. Since the experimentally obtained amounts of sorbed $\mathrm{Hg}$ (II) are less than those determined via CEC values, this also confirms the competitive effect of $\mathrm{Hg}^{2+}$ and $\mathrm{HgOH}^{+}$(Figure 1) with $\mathrm{H}^{+}$ions.

It is well known that a surface of zeolite particle has a charge depending on the $\mathrm{pH}$ value of the surrounding medium. The point of zero charge, $\mathrm{pH}_{\mathrm{pzc}}$ of both zeolite samples is previously determined and equals $6.8 \pm 0.1$ for $\mathrm{NZ}$ and $9.8 \pm 0.1$ for FeZ [21]. This means that both zeolites become positively charged below the $\mathrm{pH}$ of $\mathrm{pH}_{\mathrm{pzc}}$ due to protonation reaction with $\mathrm{H}^{+}$ions according to reactions:

$$
\begin{gathered}
\equiv \mathrm{S}-\mathrm{OH}+\mathrm{H}^{+} \rightleftarrows \equiv \mathrm{S}-\mathrm{OH}_{2}^{+} \\
\equiv \mathrm{S}-\mathrm{FeONa}+\mathrm{H}^{+} \rightleftarrows \equiv \mathrm{S}-\mathrm{FeOH}+\mathrm{Na}^{+} \equiv \mathrm{S}-\mathrm{FeOH}+\mathrm{H}^{+} \rightleftarrows \equiv \mathrm{S}-\mathrm{FeOH}_{2}^{+}
\end{gathered}
$$

Reaction (Equation (25)) represents protonation of NZ while both reactions (Equations (25) and (26)) take place for the FeZ sample. The uptake of $\mathrm{Hg}(\mathrm{II})$ onto $\mathrm{NZ}$ and FeZ could be described by ion exchange reactions whereby mono or binuclear complexes are formed as follows [39]:

$$
\begin{gathered}
\equiv(\mathrm{S}-\mathrm{O})_{2} \mathrm{X}+\mathrm{Hg}^{2+} \rightleftarrows \equiv(\mathrm{S}-\mathrm{O})_{2} \mathrm{Hg}+\mathrm{X}^{2+} \\
\equiv(\mathrm{S}-\mathrm{O})_{2} \mathrm{X}+2 \mathrm{HgOH}^{+} \rightleftarrows \equiv 2 \mathrm{~S}-\mathrm{O}(\mathrm{HgOH})+\mathrm{X}^{2+} \\
\equiv 2 \mathrm{~S}-\mathrm{OY}+\mathrm{Hg}^{2+} \rightleftarrows \equiv(\mathrm{S}-\mathrm{O})_{2} \mathrm{Hg}+2 \mathrm{Y}^{+} \\
\equiv \mathrm{S}-\mathrm{OY}+\mathrm{HgOH}^{+} \rightleftarrows \equiv \mathrm{S}-\mathrm{O}(\mathrm{HgOH})+\mathrm{Y}^{+} \\
\equiv 2 \mathrm{~S}-\mathrm{FeONa}+\mathrm{Hg}^{2+} \rightleftarrows \equiv(\mathrm{S}-\mathrm{FeO})_{2} \mathrm{Hg}+2 \mathrm{Na}^{+} \\
\equiv \mathrm{S}-\mathrm{FeONa}+\mathrm{HgOH}^{+} \rightleftarrows \equiv \mathrm{S}-\mathrm{FeO}(\mathrm{HgOH})+\mathrm{Na}^{+}
\end{gathered}
$$

where: $\mathrm{X}$ is $\mathrm{Ca}$ or $\mathrm{Mg}$, and $\mathrm{Y} \mathrm{Na}$ or $\mathrm{K}$.

The proposed ion exchange reactions (Equations (27)-(30)) take place for the NZ sample, while reactions (Equations (27)-(32)) take place for the FeZ sample. Therefore, the main mechanism of $\mathrm{Hg}$ (II) sorption is the ion exchange of $\mathrm{Hg}$ (II) species with zeolite exchangeable cations, but under the experimental conditions, $\mathrm{pH}=2$, the competition of $\mathrm{Hg}^{2+}$ and $\mathrm{HgOH}^{+}$(Figure 1) with $\mathrm{H}^{+}$ions 
cannot be excluded, which results in the protonation of the active zeolite sites according to the reactions (Equations (25) and (26)). The confirmation whether the ion exchange only mechanism is responsible for $\mathrm{Hg}$ (II) sorption onto NZ and FeZ can be confirmed by SEM/EDS analysis of zeolites surfaces, which follows below.

Scanning electron microscopy with energy dispersive X-ray analysis (SEM/EDS) was used to gain insight into surface morphology and semi-quantitative surface chemical composition, while backscattered electrons mode (BSE) was used to provide information on the distribution, distinguishing the newly formed phases on the surface of a zeolite particle saturated with $\mathrm{Hg}$ (II). BSE image with nine marked surfaces for NZHg and eight marked surfaces for FeZHg are shown in Figure 9, while a mass percentage of the detected elements on the marked surfaces are listed in Tables 2 and 3.

For both NZHg and FeZHg, results show almost uniform elemental composition on all observed spectra except for iron and sodium, whose values fluctuate depending on the observed area. The mean values of iron mass percentages on the surface for all spectra are higher for the FeZHg compared to $\mathrm{NZHg}$, which is a consequence of the modification. After saturation, among exchangeable cations, Ca dominates on the surface of both zeolite samples but with a higher mean mass percentage for $\mathrm{NZHg}$. It is interesting to note that the mean mass percentage of $\mathrm{Na}$ on the surface of FeZHg is low, which is in agreement with the results of monitoring the concentration of exchangeable cations during the sorption process (Figure 8) where $\mathrm{Na}^{+}$was the dominant exchangeable cation in the FeZ sample. These results confirm that $\mathrm{Na}$ is exchanged with $\mathrm{Hg}$ (II) and $\mathrm{H}^{+}$ions, and that ion exchange is involved in the sorption process of $\mathrm{Hg}$ (II) onto zeolites. The binding of $\mathrm{Hg}$ (II) onto zeolites is supported by the results of mass percentages of $\mathrm{Hg}(\mathrm{II})$, whose values are very similar on all observed spectra, with it being almost twice higher for FeZHg than for $\mathrm{NZHg}$, which agrees with the experimentally obtained sorption capacities.

Unevenly distributed white agglomerates observed in Figure 9, especially in case of FeZHg, indicate the formation of a new phase on the surface of both zeolite samples. In order to expand the analysis, the magnifications of $1600 \times$ for $\mathrm{NZHg}$ and at $1900 \times$ for FeZHg were made. EDS analysis at selected three points inside and outside the agglomerates is performed, as shown in Figures 10 and 11 , and the mass percentage of the detected elements are listed in Tables 4 and 5.

The results show that formed agglomerates on both $\mathrm{NZHg}$ and FeZHg consist mainly of mercury and oxygen. The analyzed point outside the agglomerates also contains mercury on both zeolite samples but in a smaller mass percentage. This indicates that mercury is sorbed over the entire surface of the particle, where some sites on the surface are more energy efficient, i.e., they act as active centers for crystal formation and growth probably in the form of $\mathrm{HgO}$ or $\mathrm{Hg}(\mathrm{OH})_{2}$. When saturation conditions are reached, $\mathrm{Hg}(\mathrm{OH})_{2}$ can precipitate or transform into the $\mathrm{HgO}$ form $[37,40]$. The resulting formations are irregular in shape because the sorption process was conducted under well-mixed conditions. $\mathrm{Lu}$ et al. described the removal of mercury via surface complexation model and formation of $\mathrm{Hg}(\mathrm{OH})_{2}$ complexes on the surface active sites of the Mn-Fe(hydro)oxides [41].

Taking into account all the above it could be concluded that the sorption mechanism of $\mathrm{Hg}$ (II) onto both zeolites includes mainly ion exchange accompanied with surface complexation and co-precipitation of different mercury phases such as oxide and hydroxide. Although it was confirmed that precipitation could not occur in the bulk solution, looking at the micro level, the zeolite surface pH may differ from the surrounding $\mathrm{pH}$ due to the releasing of exchangeable cations from the zeolite structure which can lead to formation precipitates.

Misealides et al. in their studies [24,42] of mercury binding onto natural zeolites, in a wide range of concentrations, found that the sorption mechanism involves ion exchange, adsorption, and $\mathrm{Hg}$ precipitation, most likely in the form of $\mathrm{HgO}$ which is consistent with our observations. 


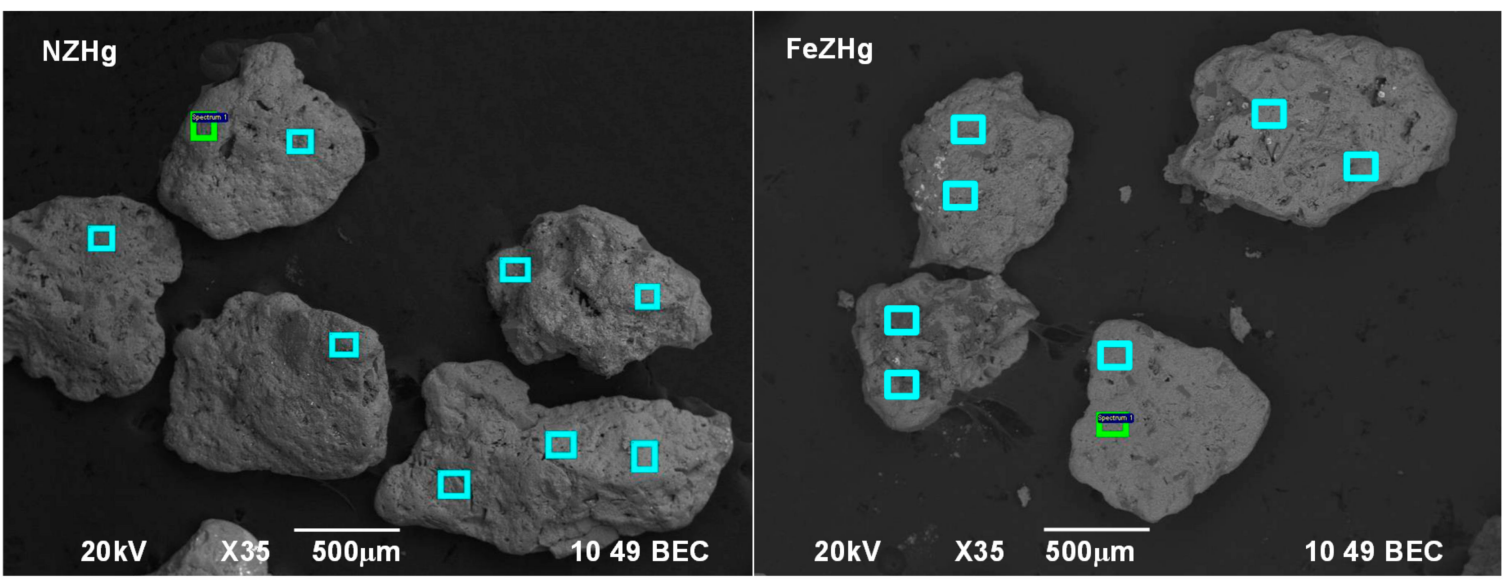

Figure 9. Backscattered electrons mode (BSE) images of $\mathrm{NZHg}$ and FeZHg with marked surfaces (Spectra, Sp) for energy dispersive X-ray (EDS) analysis.
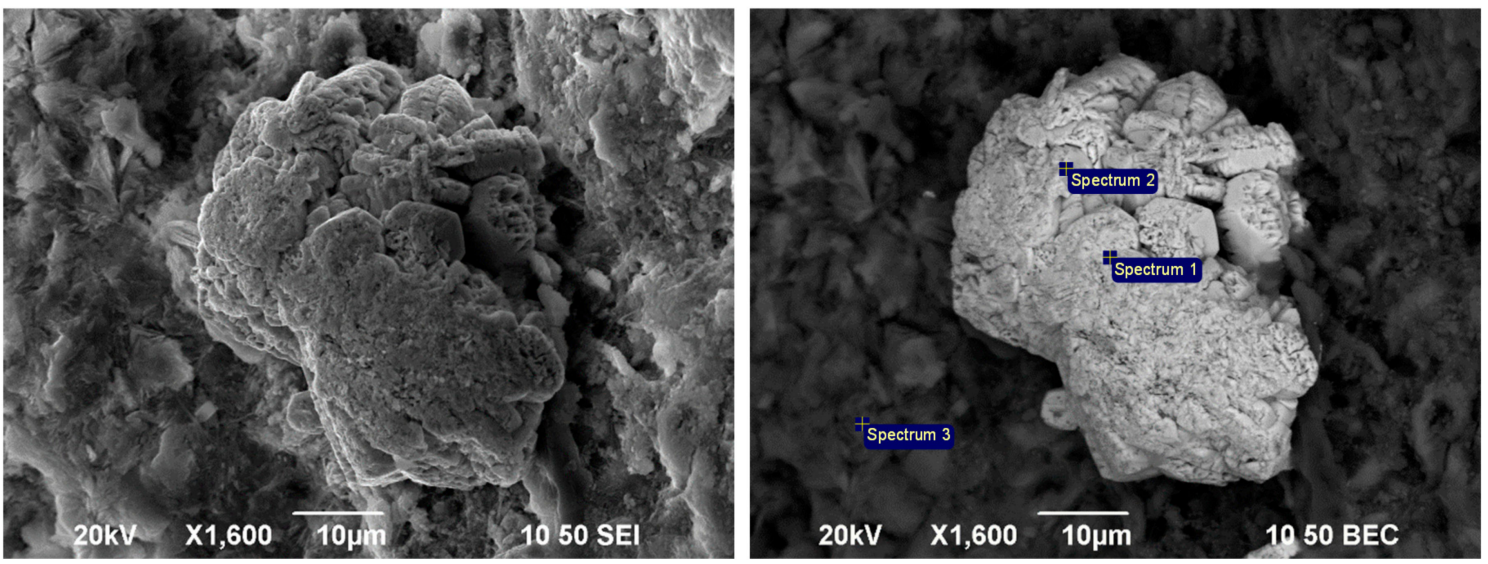

Figure 10. SEM secondary electron image (left) and corresponding backscattered electron image with three marked points for saturated NZHg (right).
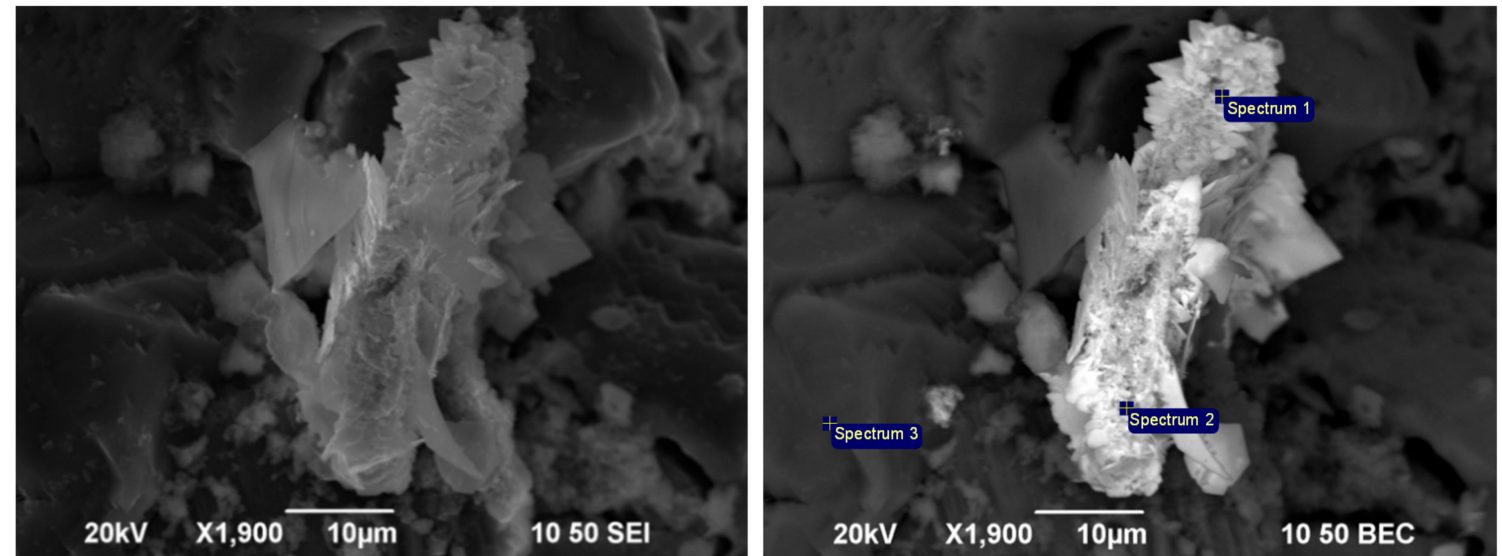

Figure 11. SEM secondary electron image (left) and corresponding backscattered electron image with three marked points for saturated FeZHg (right). 
Table 2. Mass percentage values of the detected elements on the nine marked surfaces (Spectra, Sp) for $\mathrm{NZHg}$.

\begin{tabular}{cccccccccc}
\hline Element & $\mathbf{O}$ & $\mathbf{N a}$ & $\mathbf{M g}$ & $\mathbf{A l}$ & $\mathbf{S i}$ & $\mathbf{K}$ & $\mathbf{C a}$ & $\mathbf{F e}$ & $\mathbf{H g}$ \\
\hline $\mathrm{Sp} \mathrm{1}$ & 55.71 & - & 0.48 & 5.13 & 28.52 & 0.64 & 1.23 & 0.40 & 7.89 \\
\hline $\mathrm{Sp} \mathrm{2}$ & 52.48 & 0.35 & 0.48 & 5.29 & 30.35 & 0.72 & 1.52 & 0.60 & 8.20 \\
\hline $\mathrm{Sp} \mathrm{3}$ & 47.42 & - & 0.40 & 7.19 & 34.46 & 0.74 & 2.09 & - & 7.69 \\
\hline $\mathrm{Sp} \mathrm{4}$ & 53.06 & - & 0.55 & 4.46 & 21.54 & 0.51 & 0.95 & 10.85 & 7.63 \\
\hline $\mathrm{Sp} \mathrm{5}$ & 48.02 & - & - & 7.94 & 33.17 & 0.85 & 2.27 & - & 7.74 \\
\hline $\mathrm{Sp} \mathrm{6}$ & 49.88 & - & 0.43 & 5.63 & 32.07 & 1.11 & 1.96 & - & 8.93 \\
\hline $\mathrm{Sp} \mathrm{7}$ & 55.74 & - & 0.56 & 5.21 & 28.00 & 0.70 & 1.40 & 0.40 & 8.00 \\
\hline $\mathrm{Sp} \mathrm{8}$ & 56.73 & - & 0.46 & 4.69 & 30.05 & 0.59 & 1.14 & - & 6.35 \\
\hline $\mathrm{Sp} \mathrm{9}$ & 49.45 & - & 0.58 & 6.05 & 32.00 & 0.76 & 2.11 & - & 9.05 \\
\hline Mean & 52.05 & 0.12 & 0.49 & 5.73 & 30.02 & 0.74 & 1.63 & 1.36 & 7.94 \\
\hline
\end{tabular}

Table 3. Mass percentage values of the detected elements on the eight marked surfaces (Spectra, Sp) for $\mathrm{FeZHg}$.

\begin{tabular}{cccccccccc}
\hline Element & $\mathbf{O}$ & $\mathbf{N a}$ & $\mathbf{M g}$ & $\mathbf{A l}$ & $\mathbf{S i}$ & $\mathbf{K}$ & $\mathbf{C a}$ & $\mathbf{F e}$ & $\mathbf{H g}$ \\
\hline Sp 1 & 48.92 & 0.37 & 0.38 & 4.95 & 27.84 & 0.60 & 0.75 & 1.87 & 14.32 \\
\hline Sp 2 & 53.39 & 0.33 & 0.46 & 4.91 & 25.95 & 0.48 & 0.56 & 0.55 & 13.37 \\
\hline Sp 3 & 48.62 & - & 0.43 & 5.62 & 28.10 & 0.66 & 0.66 & 0.77 & 15.15 \\
\hline Sp 4 & 44.68 & - & 0.33 & 5.65 & 30.42 & 0.76 & 0.75 & 0.81 & 16.59 \\
\hline Sp 5 & 48.98 & - & 0.39 & 4.59 & 25.98 & 0.62 & 0.46 & 5.02 & 13.60 \\
\hline Sp 6 & 49.14 & - & 0.30 & 3.46 & 21.18 & 0.44 & 0.36 & 15.11 & 9.72 \\
\hline Sp 7 & 54.86 & 1.30 & - & 4.14 & 24.37 & 0.33 & 1.61 & 0.80 & 12.60 \\
\hline Sp 8 & 48.26 & - & 0.32 & 5.29 & 31.67 & 0.48 & 0.82 & 1.35 & 11.83 \\
\hline Mean & 49.61 & 0.25 & 0.33 & 4.83 & 26.94 & 0.55 & 0.75 & 3.29 & 13.40 \\
\hline
\end{tabular}

Table 4. Mass percentage values of the detected elements on the three marked points (Spectra, Sp) for $\mathrm{NZHg}$.

\begin{tabular}{cccccccc}
\hline Spectrum & $\mathbf{O}$ & $\mathbf{M g}$ & $\mathbf{A l}$ & $\mathbf{S i}$ & $\mathbf{K}$ & $\mathbf{C a}$ & $\mathbf{H g}$ \\
\hline Sp 1 & 13.91 & - & - & 4.92 & - & - & 81.16 \\
\hline Sp 2 & 16.15 & - & 0.37 & 4.91 & - & - & 77.20 \\
\hline Sp 3 & 56.55 & 0.71 & 5.48 & 28.95 & 0.48 & 1.44 & 6.39 \\
\hline Mean & 28.87 & 0.24 & 2.20 & 38.78 & 0.16 & 0.48 & 54.92 \\
\hline
\end{tabular}

Table 5. Mass percentage values of the detected elements on the three marked points (Spectra, Sp) for FeZHg.

\begin{tabular}{ccccccccc}
\hline Spectrum & $\mathbf{O}$ & $\mathbf{M g}$ & $\mathbf{A l}$ & $\mathbf{S i}$ & $\mathbf{K}$ & $\mathbf{C a}$ & $\mathbf{F e}$ & $\mathbf{H g}$ \\
\hline $\mathrm{Sp} \mathrm{1}$ & 25.79 & - & 1.01 & 5.32 & - & - & 2.49 & 64.73 \\
\hline $\mathrm{Sp} \mathrm{2}$ & 23.37 & - & 0.96 & 4.26 & - & - & 1.85 & 69.56 \\
\hline $\mathrm{Sp} \mathrm{3}$ & 49.51 & 0.48 & 2.72 & 20.97 & 0.36 & 0.28 & 10.74 & 12.93 \\
\hline Mean & 32.89 & 0.16 & 1.56 & 10.18 & 0.12 & 0.09 & 5.03 & 49.07 \\
\hline
\end{tabular}




\subsection{Leaching Properties of the Mercury Saturated Zeolites}

Leaching properties of saturated $\mathrm{NZHg}$ and $\mathrm{FeZHg}$ were conducted in order to determine the possible application of NZ and FeZ for in situ remediation of mercury contaminated sites. The leaching test is conducted in ultrapure water in the $\mathrm{pH}$ range 2.00-12.05 according to the standard leaching method DIN 38414 [25]. The results of the amount of leached $\mathrm{Hg}$ (II) from saturated zeolites are shown in Figure 12.

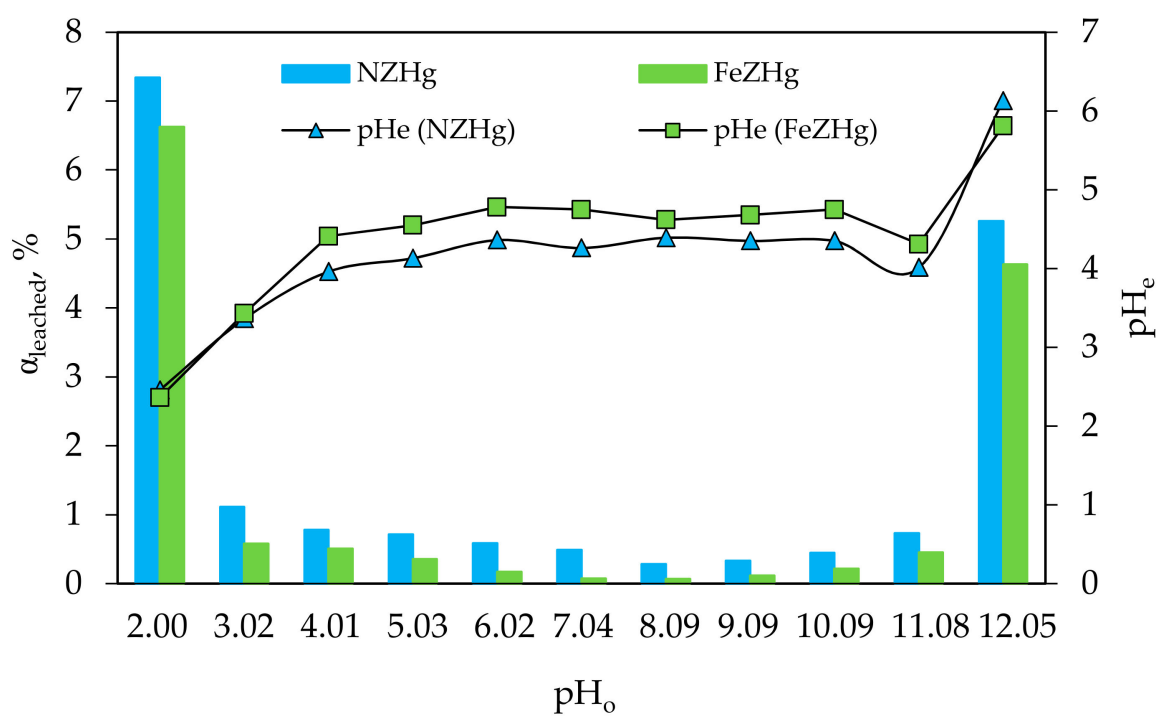

Figure 12. Amount of leached $\mathrm{Hg}(\mathrm{II})$ from saturated $\mathrm{NZHg}$ and $\mathrm{FeZHg}$ as a function of $\mathrm{pH}_{\mathrm{O}}$ as well as $\mathrm{pH}_{\mathrm{e}}$ as a function of $\mathrm{pH}_{\mathrm{o}}$.

Results presented in Figure 12 show that in a wide $\mathrm{pH}$ range, $4.01 \leq \mathrm{pH} \leq 1.08$, the leaching of mercury was observed in a small amount, only $0.28-0.78 \%$ from NZHg and $0.07-0.51 \%$ from FeZ $\mathrm{Hg}$. This indicates that mercury is firmly bound to the both zeolites. At extreme $\mathrm{pH}$ conditions, $\mathrm{pH} \leq 3.02$ and $\mathrm{pH} \geq 12.05$, leaching of mercury in an amount of $4-7 \%$ occurs from both zeolites. Generally, heavy metals can easily be released at acidic $\mathrm{pH}$ values, while at alkaline $\mathrm{pH}$ values they form insoluble hydroxides. In our case, at $\mathrm{pH} \leq 3.02$, leaching occurs due to the high quantity of hydrogen ions which displace the mercury from the zeolite structure. At $\mathrm{pH}=2.00$ and $\mathrm{pH}=3.02$, an increase in $\mathrm{pH}$ by $0.4 \mathrm{pH}$ units is observed, while for all other $\mathrm{pH}_{\mathrm{o}}$ values a decrease in $\mathrm{pH}$ is observed which tends to $\mathrm{pH} \approx 4.5$ and could be attributed to the hydroxylation of mercury species bound to the zeolite surface. The reason for leaching at extremely high $\mathrm{pH} \geq 12.05$ is due to the rupture of Si-O bonds (desilication) and degradation of the zeolite structure resulting in an increase in leached mercury. When comparing the percentage of leached mercury at all observed $\mathrm{pH}$ values, it can be noticed that the percentage of leached mercury is higher from $\mathrm{NZHg}$ than from $\mathrm{FeZHg}$, which suggests a higher affinity of $\mathrm{Hg}$ (II) towards FeZ. Furthermore, the amount of leached mercury in relation to the amount of bound mercury to $\mathrm{NZ}$ and FeZ is not significant at $4.01 \leq \mathrm{pH} \leq 11.08$ which suggests that $\mathrm{NZ}$ and especially FeZ have the ability to bind and retain mercury in its structure in a wide $\mathrm{pH}$ range. This indicates that both $\mathrm{NZ}$ and FeZ could be applied for in situ remediation of a mercury contaminated environment.

\section{Conclusions}

This study provided valuable information on $\mathrm{Hg}$ (II) sorption onto NZ and FeZ. It was noted that the sorption of $\mathrm{Hg}$ (II) was highly sensitive to the effect of $\mathrm{pH}$ and S/L ratio, especially onto FeZ, where $\mathrm{pH} \approx 2$ and $\mathrm{S} / \mathrm{L}=10$ were found to be optimal for both zeolites. The quantity of removed $\mathrm{Hg}$ (II) onto FeZ was found to be twice higher than onto NZ $(0.28 \mathrm{mmol} \mathrm{Hg} / \mathrm{g}$ and $0.54 \mathrm{mmol} \mathrm{Hg} / \mathrm{g})$. A determination of the relationship between released exchangeable cations and sorbed $\mathrm{Hg}(\mathrm{II})$ as well as 
a comparison of the CEC value with the maximum amount of sorbed $\mathrm{Hg}(\mathrm{II})$ confirmed the competition effect between $\mathrm{Hg}$ (II) species and $\mathrm{H}^{+}$ions onto both zeolite. The mechanism of $\mathrm{Hg}$ (II) sorption onto both zeolites was attributed mainly to the ion exchange, accompanied with surface complexation, which was especially pronounced for FeZ. The agglomerates on the FeZ surface were confirmed by SEM/EDS analysis, indicating possible co-precipitation. The rate-controlling step in the sorption process on heterogeneous surface of both zeolites included intraparticle diffusion accompanied by film diffusion. The leaching test confirmed the leaching of $\mathrm{Hg}(\mathrm{II})$ in extreme $\mathrm{pH}$ conditions, $\mathrm{pH} \leq 3.02$ and $\mathrm{pH} \geq 12.05$, indicating a moderate ability of zeolites to retain $\mathrm{Hg}$ (II) under these conditions. In a wide $\mathrm{pH}$ range, $4.01 \leq \mathrm{pH} \leq 11.08$, the amount of leached $\mathrm{Hg}$ (II) was not significant indicating that both zeolites were an effective materials for binding and retaining $\mathrm{Hg}(\mathrm{II})$ in their structure. In conclusion, both zeolites could be used in remediation purposes and the results suggest that modification significantly improves the sorption properties of zeolite.

Author Contributions: Conceptualization, investigation, methodology, formal analysis, writing—original draft preparation M.U.; writing — review and editing, M.U., T.Č., I.N., and M.T. All authors have read and agreed to the published version of the manuscript.

Funding: This work has been fully financially supported by the bilateral Croatian-Slovenian project "Natural modified sorbents as materials for remediation of mercury contaminated environment" (2020-2023) and the research program "Groundwater and Geochemistry (P1-0020)".

Acknowledgments: We are also thankful to the Geological Survey of Slovenia for performing the SEM/EDS analysis.

Conflicts of Interest: The authors declare no conflict of interest.

\section{References}

1. Xu, J.; Garcia Bravo, A.; Lagerkvist, A.; Bertilsson, S.; Sjöblom, R.; Kumpiene, J. Sources and remediation tehniques for mercury contaminated soil, review. Environ. Int. 2015, 74, 42-53. [CrossRef]

2. Wang, J.; Feng, X.; Anderson, C.W.N.; Xing, Y.; Shang, L. Remediation of mercury contaminated sitesA review. J. Hazard. Mater. 2012, 221-222, 1-18. [CrossRef]

3. Han, C.; Wang, W.; Xie, F. Study of the leaching of mercuric oxide with thiosulfate solutions. Metals 2016, 6, 206. [CrossRef]

4. Tejada Tovar, C.; Villabona Ortiz, Á.; Garcés Jaraba, L.E. Kinetic and adsorption mercury removal using cassava (Manhiot esculenta) and lemon (Citrus limonum) waste modified with citric acid. Ing. Univ. Bogotá (Columbia) 2015, 19, 283-298.

5. Davis, A.; Bloom, N.S.; Quee He, S.S. The environmental geochemistry and bioaccessibility of mercury in soils and sediments: A review. Risk Anal. 1997, 17, 557-569. [CrossRef] [PubMed]

6. Al-Ghouti, M.; Da'ana, D.; Abu-Dieyeh, M.; Khraisheh, M. Adsorptive removal of mercury from water by adsorbents derived from daze pits. Sci. Rep. 2019, 9, 15327-15340. [CrossRef]

7. Mayas, D.C.; Scheibe, T.D. Groundwater contamination, subsurface processes, and remediation methods: Overview of the special issue of Water on Groundwater contamination and remediation. Water 2018, 10, 1708. [CrossRef]

8. Robles, I.; Lakatos, J.; Scharek, P.; Planck, Z.; Hernández, G.; Solís, S.; Bustos, E. Characterization and remediation of soils and sediments polluted with mercury: Occurrence, transformations, environmental considerations and San Joaquin's Sierra Gorda Case. In Environmental Risk Assessment of Soil Contamination; Hernandez Soriano, M.C., Ed.; IntechOpen: New York, NY, USA, 2014; pp. 827-850. [CrossRef]

9. Thiruvenkatachari, R.; Vigneswaran, S.; Naidu, R. Permeable reactive barrier for groundwater remediation. J. Ind. Eng. Chem. 2008, 14, 145-156. [CrossRef]

10. Silva, H.S.; Ruiz, S.V.; Granados, D.L.; Santángelo, J.M. Adsorption of mercury(II) from liquid solutions using modified activated carbons. Mater. Res. 2010, 12, 129-134. [CrossRef]

11. Xia, M.; Chen, Z.; Li, Y.; Li, C.; Ahmad, M.N.; Cheema, W.A.; Zhu, S. Removal of Hg(II) in aqueous solutions through physical and chemical adsorption principles, review. RSC Adv. 2019, 9, 20941-20953. [CrossRef]

12. Wang, S.; Peng, Y. Natural zeolites as effective adsorbents in water and wastewater treatment. Chem. Eng. J. 2010, 156, 11-24. [CrossRef]

13. Shi, W.; Shao, H.; Li, H.; Shao, M.; Du, S. Progress in the remediation of hazardous heavy metal-polluted soils by natural zeolite. J. Hazard. Mater. 2009, 170, 1-6. [CrossRef] [PubMed] 
14. Misealidis, P. Application of natural zeolites in environmental remediation: A short review. Microp. Mesopor. Mater. 2011, 144, 15-18. [CrossRef]

15. Awad, F.S.; AbouZied, K.M.; Abou El-Maaty, W.M.; El-Wakil, A.M.; El-Shall, M.S. Effective removal of mercury(II) from aqueous solutions by chemically modified graphene oxide nanosheets. Arab. J. Chem. 2020, 13, 2659-2670. [CrossRef]

16. Doula, M.K. Removal of $\mathrm{Mn}^{2+}$ ions from drinking water by using Clinoptilolite and a Clinoptilolite-Fe oxide system. Water Res. 2006, 40, 3167-3176. [CrossRef] [PubMed]

17. Dimirkou, A. Uptake of $\mathrm{Zn}^{2+}$ ions by a fully iron-exchanged clinoptilolite. Case study of heavily drinking water samples. Water Res. 2007, 41, 2763-2773. [CrossRef]

18. Doula, M.K. Synthesis of a clinoptilolite-Fe system with high Cu sorption capacity. Chemosphere 2007, 67, 731-740. [CrossRef]

19. Han, R.; Zou, L.; Zhao, X.; Xu, Y.; Xu, F.; Li, Y.; Wang, Y. Characterization and properties of iron oxide-coated zeolite as adsorbent for removal of copper (II) from solution in fixed bed column. Chem. Eng. J. 2009, 149, 123-131. [CrossRef]

20. Kragović, M.; Daković, A.; Sekulić, Ž.; Trgo, M.; Ugrina, M.; Perić, J.; Gatta, G.D. Removal of lead from aqueous solutions by using the natural and Fe(III)-modified zeolite. Appl. Surf. Sci. 2012, 258, 3667-3673. [CrossRef]

21. Ugrina, M.; Vukojević Medvidović, N.; Daković, A. Characterization and environmental application of iron-modified zeolite from the Zlatokop deposit. Desalin. Water Treat. 2015, 53, 3557-3569. [CrossRef]

22. Chojancki, A.; Chojancka, K.; Hoffmann, J.; Górecki, H. The application of natural zeolites for mercury removal: From laboratory tests to industrial scale. Miner. Eng. 2004, 17, 933-937. [CrossRef]

23. Gebremedhin-Haile, T.; Olguín, M.T.; Solache-Ríos, M. Removal of mercury ions from mixed aqueous metal solutions by natural and modified zeolitic minerals. Water Air Soil Pollut. 2003, 148, 179-200. [CrossRef]

24. Misealides, P.; Godelitsas, A. Removal of heavy metals from aqueous solutions using pretreated natural zeolitic materials: The case of mercury(II). Toxicol. Environ. Chem. 1995, 51, 21-29. [CrossRef]

25. Doušová, B.; Grygar, T.; Martaus, A.; Fuitová, L.; Koloušek, D.; Machovič, V. Sorption of As ${ }^{\mathrm{V}}$ on aluminosilicates treated with $\mathrm{Fe}^{\mathrm{II}}$ nanoparticles. J. Colloid Interface Sci. 2006, 302, 424-431. [CrossRef] [PubMed]

26. US EPA. Cation-Exchange Capacity of Soils (Ammonium Acetate): Test Methods for Evaluating Solid Waste. SW-846, Method 9080; US EPA, Office of Solid Waste and Emergency Response: Washington, DC, USA, 1986.

27. DIN 38414 S4 German Standard Procedure for Water, Wastewater and Sediment Testing-SLUdge and Sediment. Determination of Leachability; Institute Institut für Normung: Berlin, Germany, 1984.

28. Kumar Vasanth, K. Linear and non-linear regression analysis for the sorption kinetics of methylene blue onto activated carbon. J. Hazard. Mater. B 2006, 137, 1538-1544. [CrossRef] [PubMed]

29. Kumar, D.; Gaur, J.P. Chemical reaction- and particle diffusion-based kinetic modeling of metal biosorption by a phormidium sp.-dominated cyanobacterial mat. Bioresour. Technol. 2011, 102, 633-640. [CrossRef]

30. Bangham, D.H.; Sever, V. An experimental investigation of the dynamical equation of the process of gass-sorption. Philos. Mag. 1925, 49, 935-944. [CrossRef]

31. Helferich, F. Ion Exchange; Mc Graw-Hill Inc.: New York, NY, USA, 1962; pp. 250-322.

32. Apiratikul, R.; Pavasant, P. Sorption of $\mathrm{Cu}^{2+}, \mathrm{Cd}^{2+}$, and $\mathrm{Pb}^{2+}$ using modified zeolite from coal fly ash. Chem. Eng. J. 2008, 144, 245-258. [CrossRef]

33. Wilczak, A.; Keinath, T.M. Kinetics of sorption and desorption of copper(II) and lead(II) on activated carbon. Water Environ. Res. 1993, 65, 238-244. [CrossRef]

34. Foo, K.Y.; Hameed, B.H. Insight into the modelling of adsorption isotherm systems, review. Chem. Eng. J. 2010, 156, 2-10. [CrossRef]

35. Vijayaraghavan, K.; Padmesh, T.V.N.; Palanivelu, K.; Velan, M. Biosorption of nickel(II) ions onto Sargassum wightii: Application of two-parameter and three-parameter isotherm models. J. Hazard. Mater. B1 2006, 33, 304-308. [CrossRef] [PubMed]

36. Nazarenko, V.A.; Antonovich, V.P.; Nevskaja, E.M. Metal Ions Hydrolysis in Dilute Solutions; Atomizad: Moscow, Russia, 1979; pp. 34-47.

37. Powell, K.J.; Brown, P.L.; Byrne, R.H.; Gajda, T.; Hefter, G.; Sjöberg, S.; Wanner, H. Chemical speciation of

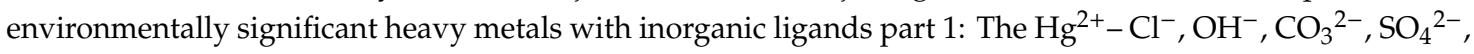
and $\mathrm{PO}_{4}{ }^{3-}$ aqueous systems. Pure Appl. Chem. 2005, 77, 739-800. [CrossRef] 
38. Minceva, M.; Fajagar, R.; Markovska, L.; Meshko, V. Comparative study of $\mathrm{Zn}^{2+}, \mathrm{Cd}^{2+}$, and $\mathrm{Pb}^{2+}$ removal from water solution using natural clinoptilolitic zeolite and commercial granulated activated carbon. Equilibrium and adsorption. Sep. Sci. Technol. 2008, 43, 2117-2143. [CrossRef]

39. Strumm, W.; Morgan, J.J. Aquatic Chemistry, Chemical Equilibria and Rates in Natural Waters, 3rd ed.; John Wiley \& Sons: New York, NY, USA, 1996; pp. 533-573.

40. Chai, L.; Wang, Q.; Wang, Y.; Li, Q.; Yang, Z.; Shu, Y. Thermodynamic study on reaction path of Hg(II) with S(II) in solution. J. Cent. South Univ. Technol. 2010, 17, 289-294. [CrossRef]

41. Lu, X.; Huangfu, X.; Ma, J. Removal of trace mercury(II) from aqueous solution by in situ formed Mn-Fe(hydro)oxides. J. Hazard. Mater. 2014, 280, 71-78. [CrossRef] [PubMed]

42. Misealides, P.; Godelitsas, A.; Charistos, V.; Ioannou, D.; Charistos, D. Heavy metal uptake by zeoliferous rocks from Metaxades, Thrace, Greece: An exploratory study. J. Radioanal. Nucl. Chem. 1994, 183, 159-166. [CrossRef]

Publisher's Note: MDPI stays neutral with regard to jurisdictional claims in published maps and institutional affiliations.

(C) 2020 by the authors. Licensee MDPI, Basel, Switzerland. This article is an open access article distributed under the terms and conditions of the Creative Commons Attribution (CC BY) license (http://creativecommons.org/licenses/by/4.0/). 